Article

\title{
Impacts Generated by a Large-Scale Solar Photovoltaic Power Plant Can Lead to Conflicts between Sustainable Development Goals: A Review of Key Lessons Learned in Madagascar
}

\author{
Carole Brunet ${ }^{1, *}$, Oumarou Savadogo ${ }^{2}$, Pierre Baptiste ${ }^{1}$, Michel A Bouchard ${ }^{3}$, \\ Jean Chrysostome Rakotoary ${ }^{4}$, Andry Ravoninjatovo ${ }^{4}$, Céline Cholez ${ }^{5}$, Corinne Gendron ${ }^{6}$ and \\ Nicolas Merveille ${ }^{6}$ (D) \\ 1 Department of Mathematics and Industrial Engineering, Polytechnique Montreal, \\ Montreal, QC H3C 3A7, Canada; pierre.baptiste@polymtl.ca \\ 2 Department of Chemical Engineering, Polytechnique Montreal, Montreal, QC H3C 3A7, Canada; \\ oumarou.savadogo@polymtl.ca \\ 3 Civil, Geological and Mining Engineering Department, Polytechnique Montreal, \\ Montreal, QC H3C 3A7, Canada; michel.bouchard@polymtl.ca \\ 4 National Office for the Environment, Antananarivo 101, Madagascar; jcrakotoary@gmail.com (J.C.R.); \\ andry.pnae@gmail.com (A.R.) \\ 5 Grenoble INP Institute of engineering, Grenoble Alpes University, 38031 Grenoble, France; \\ celine.cholez@grenoble-inp.fr \\ 6 Strategy and social and environmental responsibility Department, University of Quebec in \\ Montreal (UQAM), Montreal, QC H3C 3P8, Canada; gendron.corinne@uqam.ca (C.G.); \\ merveille.nicolas@uqam.ca (N.M.) \\ * Correspondence: carole.brunet@polymtl.ca; Tel.: +1-514-507-23-04
}

Received: 10 July 2020; Accepted: 5 September 2020; Published: 10 September 2020

\begin{abstract}
In a context of energy transition towards renewable energies, this case study situated in Madagascar allows us to verify the extent to which an on-grid photovoltaic solar power plant represents a vector for sustainable development. The article proposes a model for assessing sustainability from a qualitative multi-criteria perspective. This analysis fits into the theoretical question of the science of sustainability by challenging the theory of endogenous development. The innovation of this research is based on the use of a qualitative approach to a technological issue filling a literature gap in the major issue of the effective sustainability of renewable energy (particularly in the context of an island state). The study emphasizes that the plant can only represent a vector for sustainable development with the collaboration of the concerned parties, which implies considering the electrification needs at the local level. The article confirms that the impacts generated by the power plant can lead to conflicts between different sustainable development goals. Theoretically, the study emphasizes that the evaluation of the sustainability of solar power plants should follow a process that: (i) uses a preferably qualitative methodology likely to understand the local conditions of the communities in which they are established; (ii) identifies dissociated indicators while taking into account the context; and (iii) analyzes the possible negative interactions between the impact areas by highlighting the key areas linked to land management and the well-being of women within a poverty reduction approach.
\end{abstract}

Keywords: renewable energy; solar; photovoltaic; sustainability; multi-criteria analysis; sustainable development goals; endogenous development; poverty; developing country 


\section{Introduction}

"Africa can lead the world in low-carbon power development by embracing the revolution in clean energy" according to Kofi Annan (1938-2018), former Secretary-General of the United Nations and 2001 Nobel Peace Prize winner [1]. A breath of optimism is currently fueling the energy sector of the African continent. Despite the 620 million people without modern access to electricity, the continent has an enormous potential in natural resources which represents an opportunity for its electrification thanks to renewable energies (RE) [2].

By betting on RE, the actors assume a positive link between the technological development of "green" energies and economic and human development. Through this case study, we attempt to verify this hypothesis by evaluating the sustainability of a photovoltaic (PV) solar power plant. The study helps elucidate the conditions for setting up a solar power plant in one of the most economically vulnerable countries in the world, the island of Madagascar [3,4]. Our research question is as follows: To what extent does the presence of the photovoltaic solar power plant located in Ambatolampy represent a vector for sustainable development (SD) in a strategy for energy security and poverty reduction? The study shows that the impacts generated by the power plant can lead to conflicts between the different areas of sustainable development goals.

The originality of this research is based on the use of a qualitative approach that applies social science tools to a technological issue in a field where the quantitative approach is usually predominant. The research also helps to fill the gap in the appropriate literature to address the major issue of the effective sustainability of renewable energy (especially for an island state). It is also critical to feed appropriate strategies and policies stimulating socio-economic growth adapted to decentralized resource planning.

To date, the impact of photovoltaic solar energy on the sustainable development of African countries [5] remains more limited to an analysis based on the three pillars (economic, social, and environmental) [6,7]. In addition, the authors [8-15] specialize more in the area of decentralized off-grid photovoltaic equipment which corresponds more to the needs of the most vulnerable, both for logistical and financial reasons. Some authors have developed an analysis of on-grid power plants but in a compartmentalized manner: for their performance ([16], their impact on their social acceptance [17,18], biodiversity [19], their visual impacts [20,21], their integration context [22], and the integration of their production onto the electricity network $[23,24]$ mostly because of the challenges posed by the intermittence of variable renewable energies (VRE) in the grid. Aspects of spatial justice linked with land dispossession were also studied by some authors with a specific focus in India $[25,26]$. To date, there is no literature that holistically considers the impacts of PV solar power plants, particularly in Africa where they are most suitable due to the sunlight conditions [27]. This is where the interest of this research is lodged.

Regarding the theoretical framework, the other benefit of the case study is that it presents a model of analysis rooted, from a theoretical point of view, in the science of sustainability [28] by challenging endogenous development defined as a development based mainly on local actors, resources and cultures [29]. Stimulated by Kates in 2001 [30,31], the science of sustainability is based on a mix of relatively complex transdisciplinary approaches, defined as "reflexive, integrative, method-driven scientific principles aiming at the solution or transition of societal problems and concurrently of related scientific problems by differentiating and integrating knowledge from various scientific and societal bodies of knowledge" [32].

Assessing sustainability-i.e., "to determine whether or not a particular proposal, initiative or activity is sustainable or not" [33]—has fueled literature for many years [33,34]. It is a legitimate concern that is met with several challenges. First, assessing sustainability is based on a concept that is difficult to define [35]: sustainable development. The definition of "sustainable development" indeed includes a variety of approaches, principles, and models depending on the context of implementation; in line with its historic roots, the environmental impact study $[33,36]$ mainly centered on the three pillars (economy, environment, society) [33]. Figure 1 summarizes a variety of theoretical approach 
to the concept of sustainable development. Due to the multiplicity of concepts and their limits, four principles of sustainability were transversally identified around normativity by Waas in 2011 [37,38] for whom sustainable development is a social construct based on normative choices, equity, integration, and dynamics, namely the process of change. Waas defines sustainability as an objective "aimed at a just and equitable society, with respect for the integrity of the planet-its living species, its survival systems, and its non-living elements" [37], this definition being close to that of Gendron and Revéret in 2000 [39] which defines sustainability as "a broad approach encompassing environmental and economic but also social aspects with the main aim of meeting basic human needs and the quality of life of current and future populations". This paper falls along these lines and is focused on those principles of sustainability and its basic objective (Figure 1) while identifying a balance created by the energy tool between sustainability and poverty.

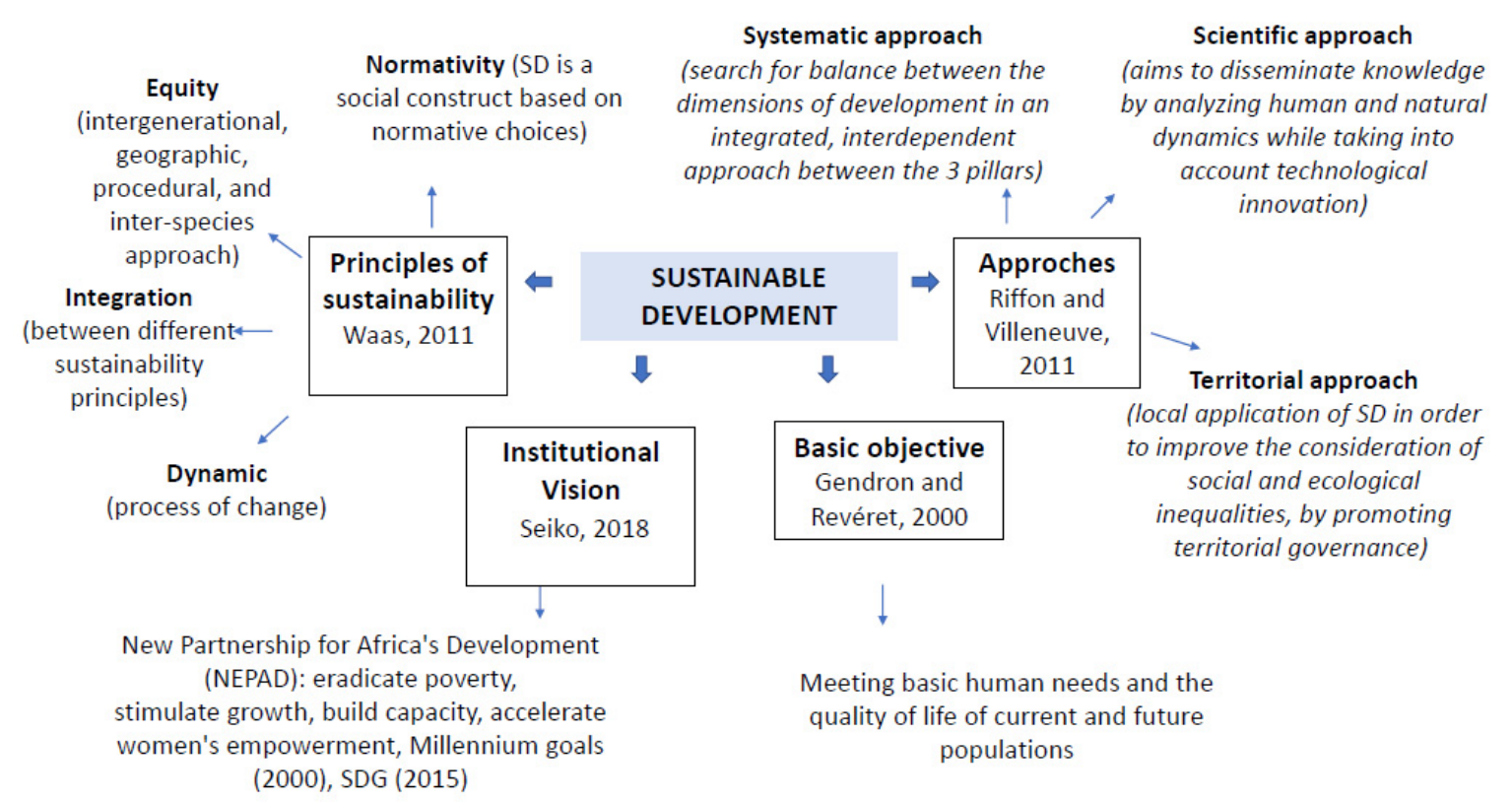

Figure 1. Theoretical approach to the concept of sustainable development according to the study.

In addition, the notion of sustainability raises a variety of issues including governance, the participation of the civil society, human rights, the role of women [35], food security [40], conflict resolution, land rights for the poorest, and sustainable economic growth [41]. In a typology of the SD presented by Riffon and Villeneuve from 2011 [42,43], the numerous issues requiring consideration lead to territorial, systemic, and scientific approaches. This paper has attempted to integrate these various approaches while addressing the variety of issues stated above, particularly in the African context.

Finally, according to Seiko et al., in 2018 [35], the practice of sustainable development in Africa also requires an "institutionalized sustainable development" approach that optimizes the use of resources. This paper acknowledges the need for "an integrated, place-based science will require new research strategies and institutional innovations to enable them especially in developing countries still separated by deepening divides from mainstream science" Kates et al. [30]. In 2017, Gasparatos et al. [44] noted the low contribution of African authors to the science of sustainability, a finding made by in 2001, Kates and Dasgupta in 2007 [41] (considering that the science of fundamental and applied sustainability must be included in the dynamics and the problem of poverty in Sub-Saharan Africa), and Wiek et al. in 2012 (hoping to stimulate networks between research bodies in collaboration with developing countries in order to achieve sustainable transformation, the potential of which remains limited) [31]. In fact, the year after the adoption of the Millennium Development Goals (2000), the New African Initiative made a plea to "eradicate poverty and place their countries, both individually and collectively on a path of sustainable growth and development". There are multiple areas of intervention, giving rise 
to NEPAD (New Partnership for Africa's Development) [45], a multi-sectoral framework based on the concept of SD [45].

In addition to the challenge of identifying an adequate definition of SD, the second difficulty in measuring sustainability is the variety of methods and indicators [46] that allow for its operationalization and understanding (or how to measure the immeasurable according to Bell and Morse [47]) according to the research fields [33]. In 2001, Bell and Morse dissociated the quantitative and explicit indicators from the qualitative and implicit indicators [48]. In 2007, Ness et al. [49], followed by Singh et al. in 2009 [46], listed several categories, dissociating: (i) indicators and indices, which can be non-integrated and integrated, (ii) assessment tools based on flow of materials and/or energy from a life cycle perspective, and (iii) integrated evaluation, based on the evaluation of policies or projects. Other authors [50,51] classify the levels of approaches integrating top-down indicators (frameworks of indicators defined by experts, then applied to research) and bottom-up indicators (indicators selected by the stakeholders). Note that for Pissourios [52], the analysis of the choice of indicators reveals that sustainability assessments are often limited to the area of specialization of the authors, which does not favor the publication of interdisciplinary assessments. Also, Blanchet, in 2012, encouraged taking into account two principles [53,54] that the case study applied: (i) dissociating development and sustainability by choosing a series of indicators rather than a synthetic one, and (ii) avoiding an overly quantitative, overly accountable approach to measuring collective performance.

As far as the sustainability of energy systems is concerned, several studies propose different evaluation models, with the number of indicators varying from four to 75 , bearing in mind that all of them include the three dimensions [55]. With regard specifically to renewable energies, two models are proposed: GSI (general sustainability indicator) [56] and SEDI (Sustainable Energy Development Index) [57]. Regarding electrification in rural areas and developing countries, four to six dimensions of sustainability are retained (institutional, economic, environmental, socio/cultural, organizational, and technical aspects) [58,59], as presented in Figure 2 on off-grid systems in rural areas. Note that several authors [58,60-63] mention the low involvement of women in the design of energy projects and yet their role remains central in the chosen sustainability dimensions. Regarding the impacts of solar power plants, Stoms et al. presented a multi-criteria spatial method in 2013 "for modeling risk of conflict with biological resources" in California [19] and two other authors propose a method to quantitatively assess the visual and aesthetic impacts of renewable energy installations [20,21].

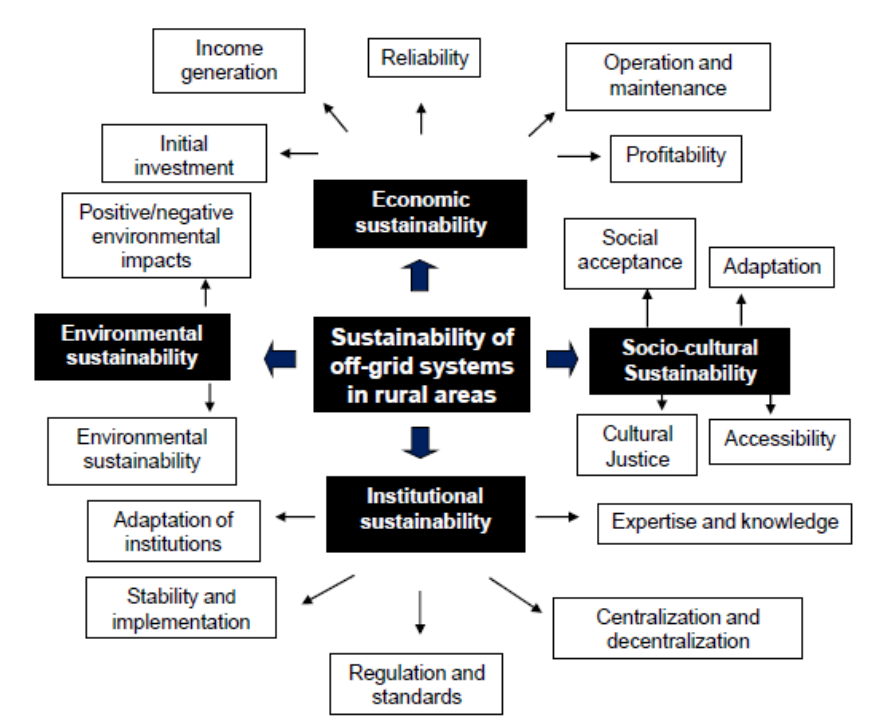

Figure 2. Sustainability indicators for off-grid photovoltaic (PV) systems in rural areas in developing countries; inspired by [58]. 
In this methodological landscape, our research is characterized by a choice of indicators that are appropriate for the context (in terms of the characteristics of sustainability specific to the African continent and according to the energy system studied); they are qualitative, integrated, and have a top-down tendency. Bottom-up or community-based indicators that are more suited to the local level [50] would have made it possible to relate more adequately to the chosen systemic, territorial, and scientific approach to sustainable development, but would have made it difficult to compare several case studies from different countries. However, the qualitative approach allows a phase of observation and better understanding of the socio-cultural context in which the solar power plant is found, using a participatory approach which can capture the resilience of the communities [64]. We have therefore also adopted a bottom-up rationale as illustrated in Figure 3, following Féron et al. in 2016 in Chile, [58] who use a qualitative method (semi-structured interviews), which Yadoo and Cruickshank also used in 2012 (Nepal, Peru, Kenya) [65]. Their approach is focused on poverty reduction within the framework of green energies. The advantages of the qualitative approach in sustainability science are also emphasized by Alexander et al. in 2019 [66], who mention the wealth of data available thanks to this method and their adaptation to complex socio-environmental contexts: "qualitative data presents untapped opportunities for sustainability science". In the Appendix A, Figure A1 provides an overview of the historical framework of key research references.

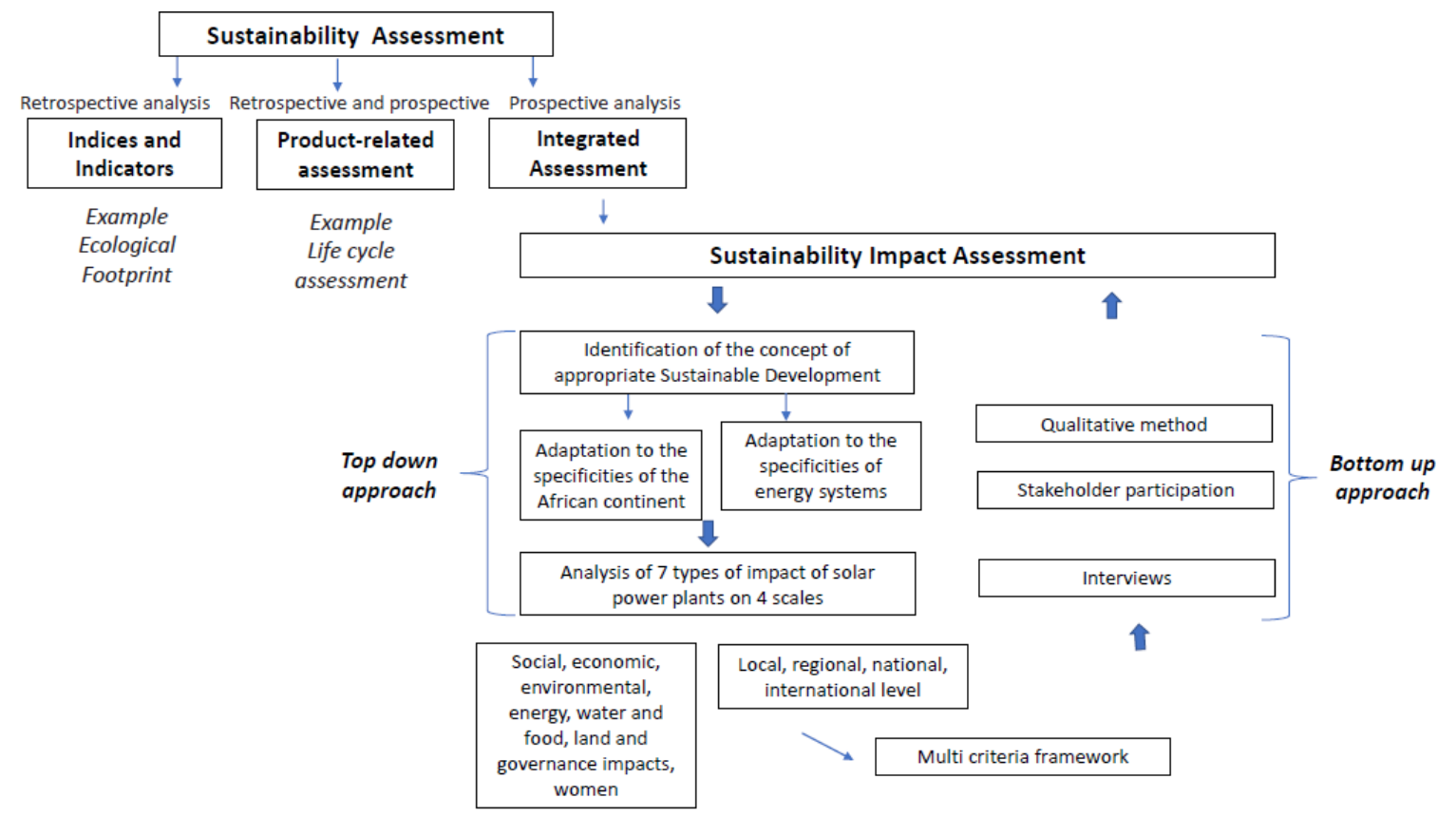

Figure 3. Sustainable Impact Assessment, theoretical approach to research. Source: [49], and the authors.

\section{Methods and Context}

Our approach is not to analyze the impacts of electricity; rather, we focus on analyzing the impacts of how to deliver this service. This case study based on a qualitative methodology [67-70] was conducted in July 2019 in Madagascar with 79 interviews whose characteristics are specified in Table 1. The study is based on the interview of the main actors involved in the operation of the solar power plant and the study was conducted in accordance with the Declaration of Helsinki, and the protocol was approved on 11 February 2019, by the Ethics Committee of Polytechnique Montreal (Research Ethics Committee 1819-44). The interviews were conducted using a pre-established questionnaire which was used to carry out similar studies on solar power plants located in South Africa, Burkina Faso, Morocco, Rwanda, and Senegal. All subjects gave their informed consent for inclusion before they participated in the study. In the case of the Madagascar power plant, the main actors are the private operator (owner of the power plant), the populations located near the power plant, actors working in 
development cooperation, as well as various authorities such as representatives of the surrounding villages, those of the district, the region, and of JIRAMA (Water and Electricity Utilities). In addition, several documents, statistics, and reports from peer-reviewed and gray literature have been used or mentioned in this article.

Table 1. Interviewed groups.

\begin{tabular}{cccccccc}
\hline \multicolumn{2}{c}{ Sex } & \multicolumn{3}{c}{ Age (years) } & \multicolumn{3}{c}{ Level of Education } \\
\hline Male & Female & $18-25$ & $26-46$ & 46 and + & $\begin{array}{c}\text { Unschooled or } \\
\text { elementary } \\
\text { level }\end{array}$ & $\begin{array}{c}\text { High } \\
\text { school }\end{array}$ & University \\
\hline 39 & 40 & 13 & 41 & 25 & 32 & 22 & 25 \\
\hline & 79 & & 79 & & & 79 & \\
\hline
\end{tabular}

While "impacts" may be theoretically defined as objectively measurable direct effects as compared to impacts, defined as a subjective measure of the importance of these, and possibly indirect effects, the latter is prioritized in this research in line with the selected qualitative approach and the will to let the interviewed people express their whole range of perceived impacts. To these primary sets of data coming from the verbatim reports are added another set of impacts derived from our own field observations. The impacts identified in this paper are therefore the results of a triangulation of methodological and analytical techniques allowing us to combine primary data (verbatim from interviews), secondary data (field observations, report, statistics), and accumulated knowledge of ONE (National Office for Environment in Madagascar) in the field of Environmental Impact Assessment. As a result, the reliability and validity of our research is in line with the selected qualitative approach.

In order to have an overview of the impacts of the solar power plant, four levels of impact were analyzed: impacts at the local, regional, national, and international levels. These impacts were grouped into several categories: social, economic, and environmental-impacts on energy, water, and food as well as on land, governance, and women. The impacts were classified into positive and negative impacts. Figures A2 and A3 in the Appendix A present the methodological approach used in impact classification and the conceptual approach of the study. Our objective was to identify and analyze the impacts of a PV solar power plant in its integration context. It is on this basis that we have made recommendations so that its presence fully contributes to the sustainable development of the island.

Our approach remains exploratory [71] since we went to meet the people who make up our field of research through appropriate data collection (semi-structured interviews, focus group, observations). This method allowed us to understand in depth the impacts of the Solar Power Plant by highlighting the relationships it has (or has not) forged with stakeholders. The coding procedure is carried out during the analysis of the verbatims, by creating impact tables which we then classified by indicators (7) and by levels (4). Thus, our research is abductive [72], that is to say, both inductive (close to Grounded theory, since the analysis of our empirical data leads us to the development of a theoretical formulation) and deductive (since our starting point remains the theoretical concept of sustainable development that we apply to our data). This intermediate position seems to be more appropriate to allow an analysis of the data collected using a flexible but « highly-structured framework » [71].

Regarding the context, the problem of access to energy in island states like Madagascar is highlighted in the recent literature [73-77]. Table 2 describes the main characteristics of the country; Table 3 gives an overview of the electricity consumption and production over 10 years; Figure 4 shows three recurring challenges; and Figure 5 summarizes government priorities. Like most African countries, Madagascar's energy profile is focused on biomass. Wood constitutes an essential source of energy production for basic needs (92\% of the country's total consumption), which has generated a decisive impact on deforestation (between 1950 and 2000, the island lost nearly $40 \%$ of its forest cover) [78]. In 2015, the main sources of energy were biomass (77\%), petroleum products (12\%), mineral coal $(7 \%)$, and hydroelectricity (2\%). Compared to other African islands States [73], Madagascar has 
relatively good installed capacity (in second position with $692 \mathrm{MW}$ after Mauritius (766 MW) [79]), and in first place for installed capacity linked to renewable energy (170 MW) thanks to hydroelectricity. In fact, $60 \%$ of the installed capacity ( $46 \%$ thermal, $54 \%$ hydroelectricity [79]) is actually available due to inadequate maintenance of thermal power plants [80]. Electricity production currently relies on petroleum products which the country mainly imports (USD 150 million in 2014, an increase of 100\% compared to 2009) [79].

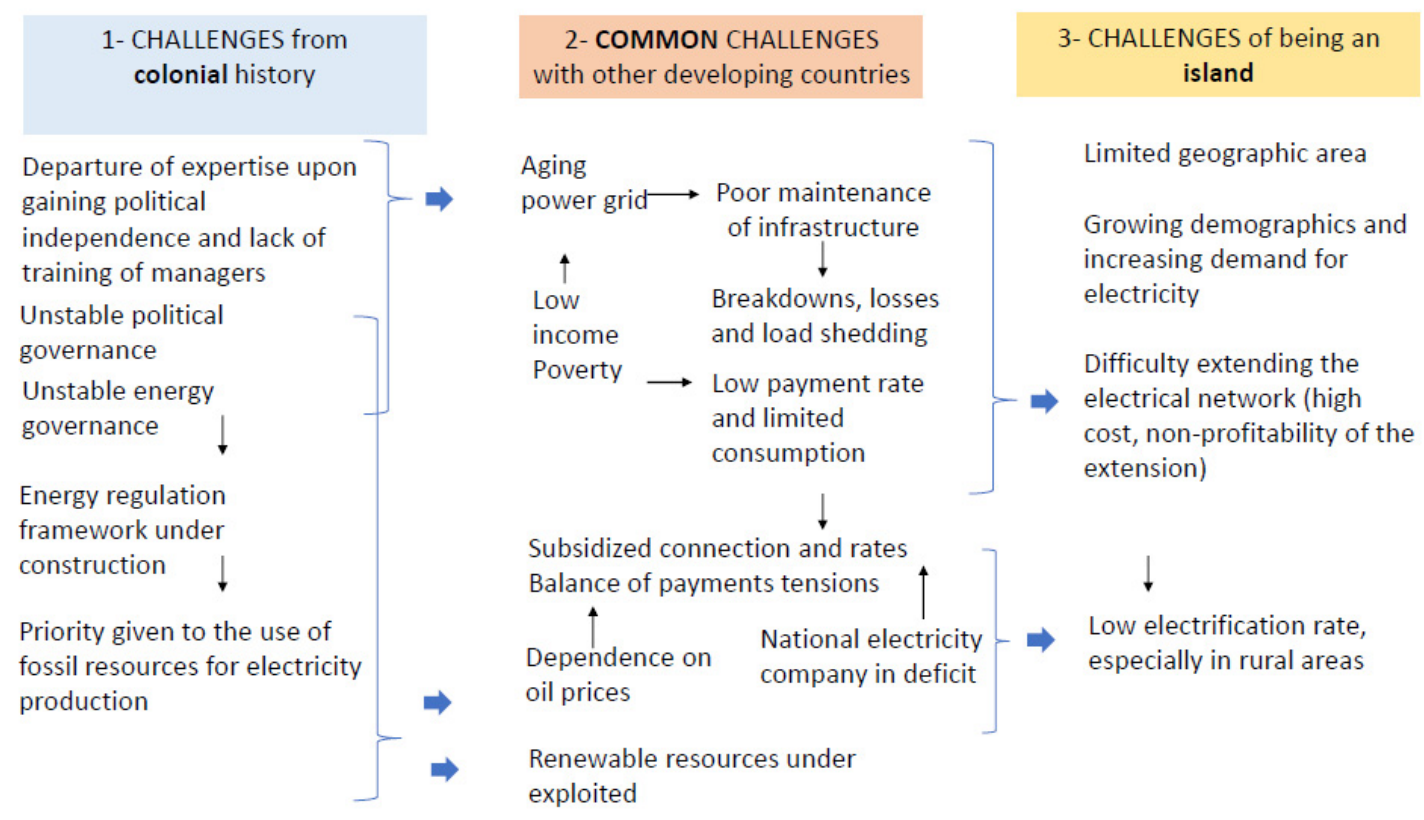

Figure 4. Three recurring challenges in the energy situation in Madagascar, according to studies carried out in the references [73-75].

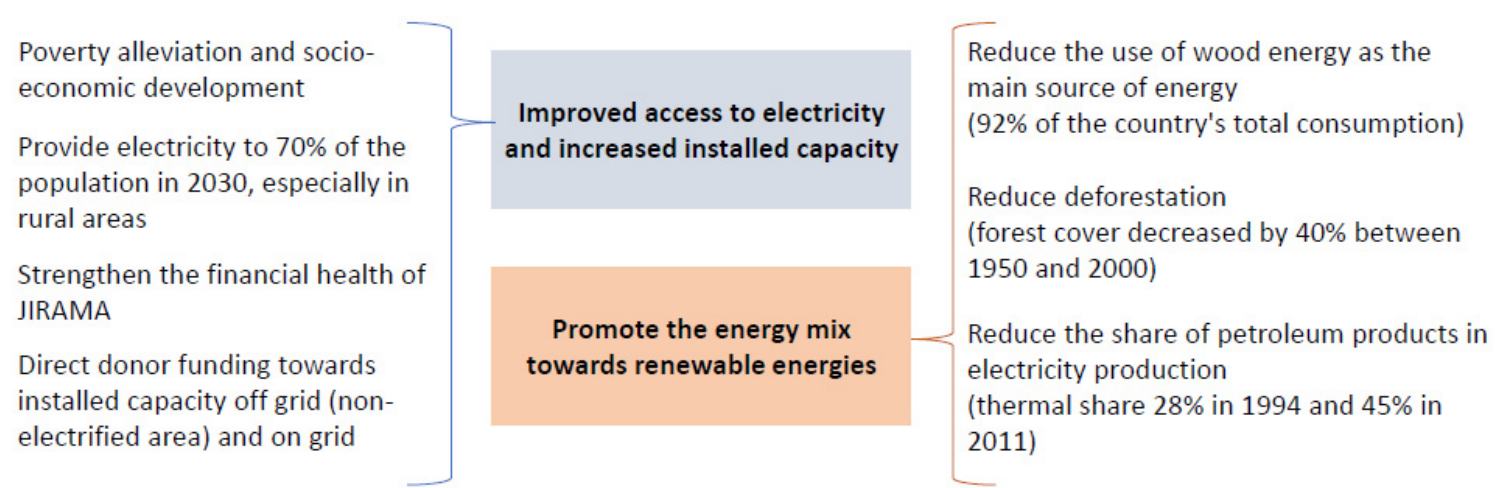

Figure 5. Government strategy.

In a tense energy context [81], the government's strategy is to rely on an increase in installed energy capacity by focusing on an energy mix with a larger share of renewable energies. Also, reducing poverty would be based on RE potential for the creation of sustainable growth [78,79]. There is a direct link between the use of REs and poverty reduction. This relationship could be explained by the electrification of isolated areas and energy access to basic social infrastructure (health and education), both favored by the reduction in the price of energy [76].

Regarding solar PV potential [82], of the $692 \mathrm{MW}$ of installed capacity, around $33 \mathrm{MW}$ comes from photovoltaic solar energy [83], which gradually came up since 2006; by 2018, $1 \%$ of the energy mix came from renewable energies [79]. This installed capacity should increase rapidly since the current 
trend of international donors is to develop the exploitation of renewable resources. The country has great potential. Indeed, solar energy production on average is $2000 \mathrm{kWh} / \mathrm{m}^{2}$ per year [79] due to sunshine that goes beyond $2800 \mathrm{~h}$ per year over the whole island [84], and some regions in the north and south can reach more than $5500 \mathrm{~h}$ [82]. Some studies measure the west coast solar radiation to be between 4000 and $6500 \mathrm{kWh} / \mathrm{m}^{2}$ [76]. The maximum daily solar radiation [82] is evaluated at around $750 \mathrm{~W} / \mathrm{m}^{2}$ with the annual average being approximately $250 \mathrm{~W} / \mathrm{m}^{2}$.

Table 2. Main characteristics of the country of Madagascar [85-91].

\begin{tabular}{|c|c|}
\hline GNI per Capita (USD) (2017) & 510 \\
\hline GDP growth (annual \%) (2018) & 4.6 \\
\hline Total population (2018) & $26,262,000$ \\
\hline Population Density inhab/km² (2018) & 45 \\
\hline Population growth (annual \%) (2018) & 2.7 \\
\hline Surface area (sq. km) (2018) & 587,295 \\
\hline$\%$ of total jobs in agriculture (2019) & $68 \%$ \\
\hline Agricultural land (\% of land area) (2016) & $71 \%$ \\
\hline Proportion of GDP from Agriculture (2016) & $20 \%$ \\
\hline Total unemployment (\% of total labor force) (2019) & $1.6 \%$ \\
\hline IDH 2018-Category & 162-Low \\
\hline Poverty headcount ratio at $\$ 1.90$ a day (2012) (\% of population) & $77 \%$ \\
\hline $\mathrm{CO}_{2}$ emissions (metric tons per capita) (2014) & 0.1 \\
\hline Access to electricity (\% of population) (2017) & $24 \%$ \\
\hline Access to electricity, rural (\% of rural population) (2017) & $17 \%$ \\
\hline Unit Prices effective 2018 for $30 \mathrm{kWh} /$ month in USD/kWh & 0.25 \\
\hline \multicolumn{2}{|c|}{$\begin{array}{l}\text { Note: Although the economic growth has been relatively stable (around } 5 \% \text { over } \\
\text { the last five years), its poverty rate remains high [92]. A large part of the economy } \\
\text { is not monetarized due to a significant rural sector [93]. Madagascar is one of } \\
\text { the least electrified countries on the African continent; the country is ranked 184th } \\
\text { out of } 190 \text { countries in terms of access to electricity, which represents one of } \\
\text { the main obstacles to the development of the country and the expansion of } \\
\text { the private sector (World Bank "Doing Business") [80,94]. The majority of } \\
\text { consumers consume at a low voltage ( } 99 \% \text { ) and consumption per capita is around } \\
50 \mathrm{kWh} / \text { year }[76,95] \text {. Over the past twenty years, the demand for electricity has } \\
\text { increased by } 5 \% \text { per year [96]. }\end{array}$} \\
\hline
\end{tabular}

Table 3. Electricity consumption and production in Madagascar [93].

\begin{tabular}{ccc}
\hline & $\mathbf{2 0 0 2}$ & $\mathbf{2 0 1 2}$ \\
\hline Production (GWh) & & \\
\hline Hydro power & 535 & 755 \\
\hline Fossil Fuels & 245 & 595 \\
\hline Solar Energy & $\mathbf{7 8 0}$ & $\mathbf{1 3 5 0}$ \\
\hline Total & 585 & 926 \\
\hline $\begin{array}{c}\text { Consumption } \\
\text { (GWh) }\end{array}$ & $\mathbf{5 8 5}$ & $\mathbf{9 2 6}$ \\
\hline Total
\end{tabular}


The following is a brief description of the photovoltaic solar power plant. The plant is located in the Vakinankaratra Region [97], the second most populous region in Madagascar. It has an average population density of 99 inhabitants per $\mathrm{km}^{2}$ (national average is 42 inhabitants $/ \mathrm{km}^{2}$ ) with a high population concentration in the urban commune of Antsirabe I (1730 inhabitants $\left./ \mathrm{km}^{2}\right)$. The solar power plant is connected to the Malagasy national electricity grid on the HV Antananarivo-Antsirabe line, one of the three interconnected HV lines that make up the Malagasy grid, the other two being those of Toamasina and Fianarantsoa. A starter station $(63 \mathrm{kV})$ located $6 \mathrm{~km}$ from the power plant allows connection to the grid, to Antananarivo or Antsirabe. The plant was commissioned in February 2018 with the official start of production beginning July 10, 2018. Its construction, which cost 25 million Euros, lasted approximately 10 months with a total of 300 employees hired both locally and nationally. It was built on equity by a private operator, a subsidiary of an international group. With $20 \mathrm{MWp}$, the power plant has no energy storage structure (planned for the future, in the event of an extension). Currently, the plant uses a $4 \mathrm{~kW}$ UPS (Uninterruptible Power Supply) powered by a generator in the event of a power outage to supply the SCADA (Supervisory Control and Data Acquisition) and internet connections. It occupies an area of 30 hectares of a total area of 55 hectares with 73,008 polycrystalline panels. The solar production has been estimated at $4.6 \mathrm{kWh} / \mathrm{m}^{2} /$ day, allowing production to power 50,000 households. It had an average of $4.91 \mathrm{kWh} / \mathrm{m}^{2} /$ day in June, the month before our study. The technology of the 73,008 panels used is polycrystalline (270 Watts and 275 Watts) mounted in an output voltage group of $750 \mathrm{~V}$ each), accompanied by 15 inverters of $1200 \mathrm{kV}$.

Several elements were taken into account when choosing the site of the plant: (i) the presence of a $63 \mathrm{kV}$ HV line halfway between Antananarivo and Tsirabé, an industrial site that has an energy demand; (ii) the flat site (1600 m altitude) formerly intended for agriculture, benefiting from a cool temperature (e.g.,13 degrees at 10:30 a.m. in July 2019) and an easterly wind cooling the panels; and (iii) good weather forecasts (one year of weather tests) estimating a production of 34 GWh per year on the basis of a power plant of $20 \mathrm{MW}$, or $1700 \mathrm{~h}$ of production per year. In terms of production, the best yields are in September/October and generally between 10:00 and 11:00 a.m. Note that besides the power plant in this study, other solar power plant projects are expected before the end of 2019 [83] in the Analamanga region and in the Vakinankaratra region, each of $5 \mathrm{MW}$.

The plant's construction project was subjected to an environmental engagement program (PREE), a procedure for projects with limited environmental impact. According to the non-technical summary of the project submitted to the ONE (National Environmental Office), within the framework of the PREE, no major or moderate impact has been identified. Note that the plant was financed by equity from a private operator. In this context, the private operator submits to the legal provisions of the country and possibly to the provisions of the international economic group to which it belongs. As emphasized by the IFDD (Francophone Institute for Sustainable Development) [98], "here, environmental assessment is replaced by the concept of environmental and social governance (ESG) of companies a proactive form of environmental and social self-governance".

\section{Results}

\subsection{Local Impacts}

\subsubsection{Economic Impacts}

Due to its location in a rural commune whose activities are mainly agricultural, the solar power plant participates in different ways of opening up the commune in which it is installed. Table A1 in the Appendix A provides a detailed inventory of the positive and negative economic impacts at the local level. There are three main points to note: employment, income-generating activities, and compensation. Firstly, the construction of the plant has generated around 300 jobs and its current operation allows the creation of 17 positions, 5 of which are permanent. Table 4 describes these jobs. Since most of the employees of the power plant live in the commune with their families, it is necessary to consider their economic impact because of the salaries which some of them receive. It 
should be noted that several local residents would have appreciated a fairer and more transparent recruitment of construction workers so that all could enjoy a source of income during the construction. Secondly, the construction of the plant involved local private operators (e.g., services of a security company, manufacture of lightning conductors on each transformer station). The development of income-generating activities around the power plant is, however, not visible, the latter being isolated from the local economic systems. The power plant nevertheless helps to secure nearby economic exchanges (transportation of crops, etc.) due to the presence of a lit road adjoining the facilities. A greater impact would have been visible if the roads around the power plant had been rebuilt. Only the road leading to the plant has been developed, bearing in mind that it is not paved. Thirdly, a sum of 20 million Ariary (USD 5500) was paid to the commune by the private operator for the installation of the plant. This sum was spent on the needs of the commune, but without particularly targeting the area located nearby.

Table 4. Description of jobs generated by the power plant.

\begin{tabular}{cc}
\hline $\begin{array}{c}\text { Total number of jobs for operation } \\
\text { of the plant: } 17\end{array}$ & $\begin{array}{c}\text { 1 Development Director } \\
\text { 1 O\&M Manager (located in Mauritius) } \\
\text { 1 Operations and maintenance manager } \\
\text { 3 Operations managers (engineer) }+1 \text { intern } \\
10 \text { cleaners: }\end{array}$ \\
$\begin{array}{c}\text { - Cleaning of the panels (2 truck drivers, } 2 \text { staff in } \\
\text { charge of the Karcher, 2 cleaners, } 1 \text { supervisor) } \\
\text { - Cleaning of premises (3 staff) }\end{array}$ \\
\hline Number of permanent jobs & 5 \\
\hline Number of temporary jobs & $\begin{array}{c}7 \text { (panel cleaning) } \\
\text { Number of positions occupied by }\end{array}$ \\
women & 2 (cleaning of premises) \\
\hline Security personnel & $\begin{array}{c}\text { Subcontracted by a private company } \\
12 \text { guards including 2 policemen }\end{array}$ \\
\hline
\end{tabular}

\subsubsection{Social Impacts}

Table A2 in the Appendix A provides a detailed inventory of social impacts at the local level. There are three main points to note: social strategy, security, and training. Firstly, the power plant made several spontaneous donations of approximately $300 \mathrm{~kg}$ of clothing and school items to the 11 schools in the five Fokontanys (neighborhoods), including a sum of 700,000 Ariary (USD 190) in school notebooks. The plant has therefore invested in various social actions at the local level. Those interviewed were often proud to realize that it is one of the priorities of the president of the island. Some residents also noted that the power plant respected the appropriate rituals specific to their culture. However, although several social initiatives have been planned for the future (installation of a phone-charging station, standpipes for residents etc.), the residents' expectations remain unfulfilled. This can be explained by limited public consultation prior to the construction of the plant (few people were consulted). Furthermore, the isolation of the local residents remains palpable (remote health units, no public transport, poor roads etc.). Finally, the plant has not formalized its social approach in a formal framework consisting of a real action plan. Also, its level of social acceptance is moderate-bearing in mind that solar technology is nevertheless generally well accepted in rural areas compared to other energy systems [98]. Secondly, for many residents, in addition to access to a better telephone network, the most visible impact for the populations is the improvement of security around the site. It should also be remembered that in the sustainability analysis of the installation, the authors included the potential theft of panels "sustainability was defined by social acceptance, environmental harm, education, theft potential, and scalability" [98]. Thirdly, as far as training is concerned, in addition to the training on the operation of the inverters, employees have developed their skills more on the job 
during operation than within theoretical training: "everyone brought their own training" said one of the employees.

\subsubsection{Environmental Impact}

As far as the environmental context of the site of the plant is concerned (the district is mainly characterized by savannah), the ONE (National Office for Environment) carried out an assessment of the various environmental issues in the Vakinankaratra region. [97] In the area of biodiversity, a deterioration has been observed, linked to the fact that there are no "notions and principles on sustainable management". Regarding soil and plant cover, several phenomena are observed, including the use of inadequate agricultural production methods. Also highlighted are the pollution of surface water and the drying up of water sources, the frequency of extreme weather phenomena, and worrying socio-economic indicators (limited access to basic infrastructure). In this context, the impacts of the power plant mentioned in the Appendix A (Table A3) neither worsen nor improve the environmental situation. There are three main points to note: pollution, fauna, and vegetation. Firstly, due to its activity being based on renewable energy, the power plant prevents the generation of 24,000 T of $\mathrm{CO}_{2}$ per year. The site does not produce noise or bad smells. Local residents do not complain about visual pollution (landscape or reflections). It should, however, be noted that there is dust pollution from the laterite road built by the plant. Regarding the material waste from the plant, boxes, and PV pallets brought during construction of the site were used by the villagers to decorate their houses. Defective panels or those at end-of-life are to be returned to China in coordination with the manufacturer. Secondly, the plant does not seem to have any significant impact on wildlife. Note, however, the possible impact of the light coming from the plant at night. Certain animals live within the site of the plant (guard dogs, snakes, mason wasps under the panels, bird nests in the ventilators, etc.). The power plant also used sheep to remove the grass growing around the panels, before inviting local residents to remove it. Thirdly, the site is surrounded by wooded areas, following tangible reforestation (not carried out by the plant). Since the land was formerly cultivated farmland, the earthworks did not have any significant impact.

\subsubsection{Energy Impacts}

Table A4 in the Appendix A provides a detailed inventory of energy impacts at the local level. Two main points are noted here: production and storage. As the power plant's production is injected into the $63 \mathrm{kV}$ grid which supplies urban and rural areas between Antananarivo and Antsirabe, it has a local impact for people already connected to the grid. However, the presence of the power plant has not had any impact on the electrification of residents living near the facilities. We note that the actual production quantity of the plant (29 GWh since it started operating in June 2018) is slightly below forecasts (34 GWh). Regarding energy storage, as mentioned in Table 5, the power plant generated the intended quantities and the vast majority of people interviewed at the local level indicated that power cuts have decreased since its installation. Unfortunately, the power produced is not stored. Consequently, in the event that the national electricity grid is not working, the electricity produced by the plant is neither used nor stored. See nomenclature table with units in the Appendix A, Table A8.

\subsubsection{Impacts on Water and Food}

Table A5 in the Appendix A provides a detailed inventory of the impacts on water and food at the local level. Concerning the availability of water, the plant has no significant impact bearing in mind that the area does not experience water stress. Furthermore, the power plant has not yet assessed the amount of water used for the cleaning carried out between August and October 2018 (no cleaning product used). Note that several respondents made a link between the presence of the plant and the fact that there is less rain, which for many, has the benefit of circumventing inconvenient floods. Regarding the impact on feeding of local residents, the main issue remains the fact that the area used by the plant is a fertile area that could have been used for local agriculture and yet according to the ONE, the region 
of Vakinankaratra [97] is characterized by poor distribution of cultivable land. Note, however, that in this region, the cultivated part in the cultivable area is 51\% which means that the area in which the power station is located is not in deficit of land to cultivate. In addition, the access roads around the plant have not been rebuilt, which can alter the transportation of crops and seeds to farmers.

Table 5. Energy production from the power plant (per month). Source: Solar Power Plant.

\begin{tabular}{cc}
\hline \multicolumn{2}{c}{ Production in GWh } \\
\hline July & 0.88 \\
\hline August & 3.00 \\
\hline September & 3.10 \\
\hline October & 3.20 \\
\hline November & 1.90 \\
\hline December & 2.66 \\
\hline 2019 & \\
\hline January & 2.45 \\
\hline February & 2.54 \\
\hline March & 2.62 \\
\hline April & 2.65 \\
\hline May & 2.32 \\
\hline June & 1.69 \\
\hline TOTAL 2018-2019 & $\mathbf{2 9 . 0 1}$ \\
\hline
\end{tabular}

\subsubsection{Impacts on Governance and Land}

Table A6 in the Appendix A provides a detailed inventory of the impacts on governance and the territory at the local level. With regards to the land, it should be noted that the power plant sits on an area of 55 ha (of which 30 ha are currently used). This land belongs to the region and is being used under a concession granted for 25 years. The presence of the plant has not had an impact on the value of the land around it and there has not been any conflict regarding the ownership of the land (according to the ONE, less than $5 \%$ of the land in the region has title deeds [97]. Respondents appreciated the fact that the land looks better with the panels installed. Note, however, that even if access to the plant has been made easy by the new laterite road, the access roads beyond the plant are poorly maintained and do not favor the local rural communities. Few impacts are to be noted as far as governance is concerned. The installation of the power plant was accompanied by payment of a fee to the commune and its presence has helped develop relationships with the concerned Fokontany (villagers have been invited to harvest the grass cover between the solar panels, there has been contact with schools, etc.). Note also that the locals feel that they were not consulted before the installation of the power plant.

\subsubsection{Impacts on the Situation of Women}

Table A7 in the Appendix A gives a detailed description of the impacts of the plant on the situation of women. Two main points are to be noted: the context and low impact. The women interviewed at the local level (villagers working along the fence of the plant, whose children are in the Fokontany schools, or who are residents nearby) share their feeling of inferiority and their difficulty in working in a structure that is dominated by men. They present their socio-cultural context: there are few educated women available to work in the plant, there are 3-15 children per family, work in the plant requires physical strength, there is a strong patriarchy, jealousy of spouses is possible especially if the work does not meet the etiquette criteria, and there is risk of gaining a bad reputation for doing night work. 
The women interviewed also explained the difficulties they face in transporting their harvest due to the condition of the access roads around the plant, and poor access to health care (in the event of a full-term pregnancy, for example) with these damaged roads. Finally, the power plant seems to have an imperceptible impact on women in general (work, health, education of children, food security, etc.). It employs two women (unskilled and temporary) out of the 13 current jobs, even though it plans to adopt a policy that is more open to female employment.

\subsubsection{Conclusion of Local Aspects}

At the local level, the positive impacts are mainly centered on the opening up effect that the presence of the plant has. This opening up is based on several factors mentioned above: enhanced security due to the night lighting and the presence of local police and guards around the plant, improved roads along the facilities (which promotes exchanges between communities), and an improved telephone network. From an economic and environmental point of view, the impacts are not significant, although the plant has created a dozen jobs and vegetation around the site has generally been preserved.

At the local level, the priority impacts to be improved mainly relate to the lack of support for rural electrification. Although the power plant is an energy source for the electricity grid, it does not contribute to the extension of electrification at the local level. In addition, women benefit little from the presence of the plant near their homes. Finally, the absence of a dynamic link to the development of income-generating activities does not promote solid social acceptance, especially since the consultations later carried out on construction remain unrepresentative of the residents.

\subsection{Regional Impacts}

Compared to local impacts, the regional impacts are much less visible. The most important impacts are centered on the economic and energy aspects, the other impacts being imperceptible. In fact, the power plant is located in the Vakinankaratra region, the most industrialized area on the island [99] which has significant electricity needs. Compared to other energy sources in the region around Anstirabe (the biggest industrial city in the country), the power plant is more powerful than other renewable energy sources emanating from hydroelectricity or thermal. Its production should therefore limit the use of firewood especially in the textile industries. However, this electrical production should also give this polluting industrial activity (textiles, tobacco, food) tangible environmental impacts. From an economic point of view and in the aforementioned logic of energy support, the power plant indirectly supports job creation and the development of the Region. It also pays an amount of 30 million Ariary per year ( 8200 USD) for the occupation of the land (27-year lease for 50 hectares). This sum is used for administrative costs at the regional level.

\subsection{National Impacts}

At the national level, the economic impacts are the most significant. The financial profitability of the plant depends on the price of the electricity it generates. This price is set in Euros due to the legal arrangements between the Malagasy government and the plant. As a result, its profitability will depend on the exchange rate between the Euro and the Ariary. However, when the project was launched, the exchange rate was 3250 Ariary. At the time of the study, it was 4000 Ariary. It turns out that JIRAMA buys the kWh produced by the plant at a price higher than that at which it sells it to consumers. Although JIRAMA does not benefit much from the power plant, it cuts its financial deficit because the cost of producing electricity in its thermal power plants is higher than the price of electricity generated by the PV power plant. The average cost of producing electricity purchased by JIRAMA "was between 1100 and $1200 \mathrm{Ar} / \mathrm{kWh}$ between 2011 and 2015. In comparison, the average selling price of electricity to all JIRAMA customers is around $380 \mathrm{Ar} / \mathrm{kWh}$ " [79]. The sale price of the electricity generated by the power plant to JIRAMA is 12.5 Euro cents, or around 480 Ariary, depending on the exchange rate between the Euro and the Ariary. Table 6 describes this data. This situation remains mitigated, however, because JIRAMA is engaged in an electricity subsidization 
strategy on a national scale which goes far beyond its financial capacity. As of June 30, 2019, the World Bank recorded arrears of 1.6 trillion Ariary [100]. Beyond the financial aspects, although the plant does not participate in the development of a PV industry in Madagascar, it does participate in stimulating the electrical networks sector (civil engineering, wiring, etc.). We also note that the development of sites based on renewable energies should lead to a reduction in the volume of hydrocarbons purchased by JIRAMA, bearing in mind that between 2009 and 2014, the amount of hydrocarbons purchased doubled (nearly USD 150 million in 2014) [79].

Table 6. Financial data on the price of electricity. Source: JIRAMA, $[79,101]$.

\begin{tabular}{cc}
\hline $\begin{array}{c}\text { Sale price of electricity generated } \\
\text { by the power plant (kWh) }\end{array}$ & $\begin{array}{c}\text { Euro 12.5 c } \\
480 \text { Ariary }\end{array}$ \\
& Euro 11.3 c (2018) \\
Electricity tariff in Madagascar & 370 Ariary-exchange rate 3250 \\
Ariary/Euro (2018) & Euro 9.25 c (2019) \\
(Consumer price) & Ariary-exchange rate 4000 \\
& Ariary/Euro (2019) \\
\hline $\mathrm{kWh}$ price-Thermal power stations & 1000 Ariary \\
(Gasoil, heavy fuel) &
\end{tabular}

Although few in number at the national level, the social impacts are positive and significant. The power plant is a source of national pride since it is the first in the Indian Ocean. It thus improves the image of Madagascar while raising awareness on a large scale of the place of renewable energies in the energy landscape. Finally, the plant contributes to strengthening capacities within the multiple collaborations undertaken (JIRAMA, ministries, private operators, donors).

Regarding environmental impacts, although the island's energy needs are constantly increasing, the presence of the plant directly contributes to reducing dependence on fossil fuels. This is a decisive point in the fight against climate change, which represents the main impact of the power plant at the national level regarding environmental impacts. However, note the non-disclosure to the public of the environmental impact study.

The main energy impact of the plant at the national level remains the increase in installed electrical capacity and participation in the island's energy mix. Since it is the first of its kind built on Malagasy soil, the plant is launching the symbol of an aggressive strategy focused on renewable energy. In addition, it was designed according to the capacity of the national grid: "The line is limited by its capacity, so we want to go beyond it. We cannot produce more than Jirama can consume". An extension is planned in the future in order to provide more electricity to Antsirabe and Ambatolampy. This extension would allow an additional $18 \mathrm{MW}$ in PV and $10 \mathrm{MW}$ in storage (using TESLA batteries) in order to regulate the intermittent production during the day and to use the electricity stored after sunset. This strategy could be effective because in terms of production, the best yields from the PV plant are during the months of September and October and generally between 10:00 a.m. and 11:00 a.m., bearing in mind that according to JIRAMA, the peak hours for electricity consumption are between 5:30 p.m. and 7:30 p.m. The peak time for electricity consumption on the island therefore does not correspond to the peak production time of the plant. In addition to this discrepancy, there are technical repercussions which generate fluctuations on the national electricity grid due to the intermittent production of the power plant.

Regarding the impacts on water and food, no significant impact is identified at the national level. As for the territorial impacts, there is none perceptible enough to be emphasized. Regarding the impacts on governance, it should be noted that the plant is classed as a "presidential project" which gives it a certain legitimacy. However, at the national level, there is centralization of decisions and information regarding the plant, which remains to be improved in order to encourage the strengthening of skills at all levels. Furthermore, it seems unlikely that the presence of the power plant will have 
a decisive impact on the development of an energy policy adapted to the specifics of PV power plants. The impact on the situation of women at the national level is quite limited. Indeed, the presence of the plant does not contribute to promoting a possible strategy favorable for a gender policy, especially within the development of renewable energies.

\subsection{International Impacts}

Just like the national impacts, the economic impacts stand out at the international level. Indeed, the economic impacts reveal that the presence of the power plant represents a strong symbol of the notoriety of the island at the international level since it is the most powerful plant in the Indian Ocean. This positive image should be emphasized for investors bearing in mind that the country is also ranked 158th out of 180 countries according to the 2019 Corruption Perception Index [102]. The Plant highlights the presence of renewable energies and Madagascar's capacity to attract private investment in line with its sustainable development and its commitments in the Conference of Parties in 2015 (COP 21). However, it should be remembered that most of the equipment used by the plant is imported (from China) and that the engineering framework is mainly centered on European collaborations without any particular attachment to the sub-region of the African continent. In the social field, the impacts are mainly centered on the sharing of skills within the parent company and its subsidiaries, especially in the Indian Ocean. In the environmental field, even if the presence of the plant reinforces the idea of an island that seeks to protect its natural capital and biodiversity, the implementation of a circular economy strategy remains far from reality.

\subsection{Summary of Impacts}

In the economic field, the impacts are significant at all levels. Admittedly, the power plant enables the highlighting of an investment of a private operator in the field of RE (international level), helps to lower the price of electricity and limits the debt burden of JIRAMA (national level), all while funding the area of installations (regional level) and promoting the economic opening up of populations at the local level. However, since most of the equipment used by the plant is imported (international level), it does not contribute to the development of a PV market in Madagascar (national level), and at the regional and local levels, the impacts are limited (lack of income-generating activities for residents).

In the social field, the impacts are limited, especially at the local level, and absent at the regional, national, and international levels. The power plant makes it possible to open up the local community and to develop large-scale PV solar energy for local residents, but its social acceptance locally remains limited.

In the environmental field, the impacts are visible at all levels. The plant highlights a strategy and symbol of energy transition (international and national levels), while reducing the use of polluting energy sources (regional level) and preserving the local setting. However, the practical application of a circular economy approach (at international and local levels) and the fact that its energy production indirectly supports polluting industries (regional level) must be considered. However, their energy source will pollute less than in the past when they only used thermal electricity.

Like in the environmental and economic sectors, the impacts in the energy sector are omnipresent. Of course, the power plant remains a powerful energy system in the Indian Ocean (international level) which boosts the installed capacity on the island (national and regional levels) and limits the frequency of power cuts. However, it remains subject to intermittent energy supply (disruption of the electrical grid, peak electricity consumption does not correspond to the peak production of the plant), bearing in mind that it does not contribute to electrification at the local level.

Concerning water and food, the impacts are mainly present at the local and regional levels. Firstly, the power plant's energy production enables the development of a regional industry that pollutes through its liquid discharges. In addition, the plant occupies a fertile agricultural area that can be used for local agriculture. 
In the area of governance and territory, the impacts are visible at the regional and national levels, not so much at the local and international levels. Few territorial issues are to be raised seeing that the plant pays an annual fee to the region (we cannot verify the use of these funds). From a governance point of view, the plant has a special regard since it is seen as a "presidential project", which also encourages a centralization of decisions and information relating to its operations. We also note that the process of consulting the populations at the local level is not unanimous.

As for women, they are invisible when it comes to impacts and this is most concerning. This indicates that the plant has not had any positive effects on the social or economic life of women, yet they are at the heart of the island's development axes. Table 7 presents a summary of the different impacts identified at the local, regional, national and international levels. Figure 6 brings together the most significant impacts of the plant.

\section{Positive impacts}

Development of regional cooperation with the Indian Ocean and limitation of GHG emissions

Pilot project promoting the energy transition to RE by stimulating the drop in the electricity price and boosting the production capacity of the island

Support for regional industrial development (decisive for the national economy) by limiting the systematic use of firewood.

\section{Impacts to be improved}

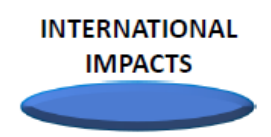

Weak collaboration with the African continent which could offer best practices. Circular economy strategy to be demonstrated.

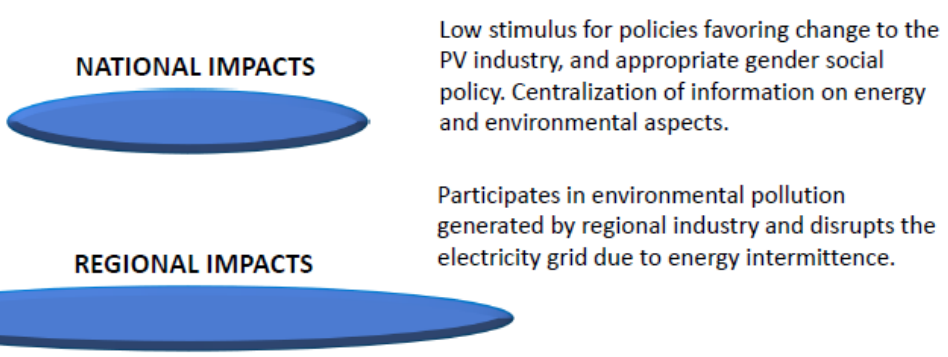

Contributes to opening up the area of establishment without major impact on deforestation and access to water.
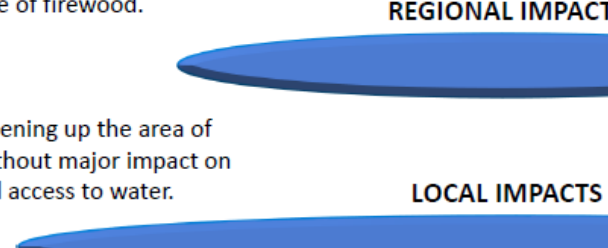

Limited social acceptance (low contribution to local electrification, income-generating activities, women's well-being) and use of an agricultural area.

Figure 6. Summary of the most significant impacts.

Table 7. Summary of impacts.

\begin{tabular}{ccc}
\hline & Major Positive Impacts & Major Impacts to Be Improved \\
\hline \hline Economic & $\begin{array}{c}\text { Promoting investment of } \\
\text { an international private operator on } \\
\text { equity }\end{array}$ & $\begin{array}{c}\text { Importation of most of the equipment } \\
\text { used by the power plant }\end{array}$ \\
\hline Social & $\begin{array}{c}\text { Sharing knowledge between } \\
\text { the entities of the international private } \\
\text { operator }\end{array}$ & Imperceptible impacts \\
\hline Environmental & $\begin{array}{c}\text { Reinforces the image of Madagascar } \\
\text { as a protected natural space }\end{array}$ & $\begin{array}{c}\text { Dynamics of circular economy at } \\
\text { the scale of the sub-region to be } \\
\text { demonstrated }\end{array}$ \\
\hline Energy & Most powerful power plant in power \\
in the Indian Ocean & Imperceptible impacts & Imperceptible impacts \\
\hline Water and food & & Lack of noticeable impacts \\
\hline
\end{tabular}


Table 7. Cont.

\begin{tabular}{|c|c|c|}
\hline & Major Positive Impacts & Major Impacts to Be Improved \\
\hline Governance and land & $\begin{array}{l}\text { Contributes to giving a positive image } \\
\text { in a context of risk/corruption }\end{array}$ & $\begin{array}{l}\text { Organizations in the sub-region have } \\
\text { limited take-up of RE }\end{array}$ \\
\hline Women & Imperceptible impacts & Imperceptible impacts \\
\hline \multicolumn{3}{|c|}{ National impacts } \\
\hline Economic & $\begin{array}{l}\text { Stimulation of reduction in price of } \\
\text { electricity supplied by RE }\end{array}$ & $\begin{array}{c}\text { Does not participate in } \\
\text { the development of the PV industry in } \\
\text { Madagascar }\end{array}$ \\
\hline Social & $\begin{array}{l}\text { Capacity building and development } \\
\text { of expertise }\end{array}$ & Imperceptible impacts \\
\hline Environmental & $\begin{array}{l}\text { Contributes to reducing dependence } \\
\text { on fossil fuels }\end{array}$ & $\begin{array}{l}\text { No access to the Environmental } \\
\text { Impact Study (not public) }\end{array}$ \\
\hline Energy & Increased energy capacity of the island & $\begin{array}{l}\text { Electricity consumption peak does not } \\
\text { correspond to the power plant's } \\
\text { production peak }\end{array}$ \\
\hline Water and food & Imperceptible impacts & Imperceptible impacts \\
\hline Governance and land & $\begin{array}{l}\text { Establishment of the site supported by } \\
\text { the State "presidential project". }\end{array}$ & $\begin{array}{l}\text { Centralization of decisions and } \\
\text { information relating to the power } \\
\text { plant at national level }\end{array}$ \\
\hline Women & Imperceptible impacts & $\begin{array}{l}\text { No drive for the development of } \\
\text { a policy that favors women. }\end{array}$ \\
\hline \multicolumn{3}{|c|}{ Regional impacts } \\
\hline Economic & $\begin{array}{l}\text { Payment of an annual allowance to } \\
\text { the Region }\end{array}$ & Lack of regional economic exchanges \\
\hline Social & Imperceptible impacts & Imperceptible impacts \\
\hline Environmental & $\begin{array}{l}\text { Limiting the use of firewood in } \\
\text { industries }\end{array}$ & $\begin{array}{c}\text { Energy support for polluting } \\
\text { industries }\end{array}$ \\
\hline Energy & Support for local regional industry & $\begin{array}{l}\text { Impact on the electricity network due } \\
\text { to intermittent production }\end{array}$ \\
\hline Water and food & Imperceptible impacts & $\begin{array}{l}\text { Risk of energy support for polluting } \\
\text { industries (wastewater discharges) }\end{array}$ \\
\hline Governance and land & $\begin{array}{l}\text { Payment of an annual allowance to } \\
\text { the Region }\end{array}$ & $\begin{array}{l}\text { Limited collaboration on the sharing } \\
\text { of information about the power plant }\end{array}$ \\
\hline Women & Imperceptible impacts & Imperceptible impacts \\
\hline \multicolumn{3}{|c|}{ Local impacts } \\
\hline Economic & $\begin{array}{l}\text { Well lit road promoting trade and } \\
\text { security }\end{array}$ & No income-generating activities \\
\hline Social & Large-scale solar awareness & Limited social acceptance \\
\hline Environmental & Limited deforestation & Equipment end of life \\
\hline Energy & Limitation of power cuts & No contribution to local electrification \\
\hline Water and food & $\begin{array}{c}\text { No negative impacts on access to } \\
\text { water }\end{array}$ & $\begin{array}{c}\text { Fertile area that can be used for local } \\
\text { agriculture }\end{array}$ \\
\hline Governance and land & $\begin{array}{l}\text { Development of relations with } \\
\text { the Fokontany }\end{array}$ & $\begin{array}{l}\text { Limited consultation with local } \\
\text { populations before installation }\end{array}$ \\
\hline Women & 2 out of 13 employees are women & $\begin{array}{l}\text { Women's jobs are temporary and for } \\
\text { the unskilled }\end{array}$ \\
\hline
\end{tabular}




\section{Discussion and Recommendations}

\subsection{Tensions between SDGs and Endogenous Development}

Our case study touches on the interdependence between the impacts of PV solar power plants on the basis of Sustainable Development Goals (SDGs) which "provide a holistic and multidimensional view on development" [103], especially for Africa which greatly contributed to their development [34]: "what if non-polluting energy sources are more expensive, thus increasing the burden on the poor, for whom they represent a larger proportion of daily expenditure? Which goal will take precedence?" Several authors have studied the interdependence of the SDGs: "Countries must interpret the SDGs according to their national circumstances and levels of development, so interaction scores will vary" [104]. With regard to SDG 7, "ensure access to affordable, reliable, sustainable, and modern energy for all", it is considered to reinforce the achievement of other goals (for example, the supply of electricity enables operation of electrical irrigation systems) or creating conditions for achieving another goal (e.g., promoting education through providing light at night) [104]. Negative correlations have also been observed "between SDG 7 and 8 (Decent work and economic growth), SDG 9 (Industry, innovation, and infrastructure), and SDG 15 (Life on land) for 25-40\% of the data pairs"; similarly, the "proportion of population with access to electricity, which is an indicator for SDG 7, has increased in some countries by expansion of non-renewable energy sources" [103]. In addition, an increase in consumption can also go against reducing waste and combating climate change [104], just as the use of renewable energies (SDG 7) can have a negative impact on zero hunger because of the agricultural areas used or the reduction of wooded areas (SDG 15) [105]. These observations are confirmed in our case study. Figure 7 gives an overview of the indicators identified for the case study according to the areas of intervention of the SDGs and Table 8 mentions the impact of the plant on the SDGs. As shown in Figure 8, these tensions between SDGs weaken the sustainability of the project by also weakening its potential to generate endogenous development [106]. This conflicts with the conviction that renewable energies are a vector for development based on a "local productive system" [107]. This article will not stop at the nuances of endogenous development [108] briefly explained in Figure 9 but it brings us closer to a literature determined to identify a concept of sustainable development specific to the African continent [109].

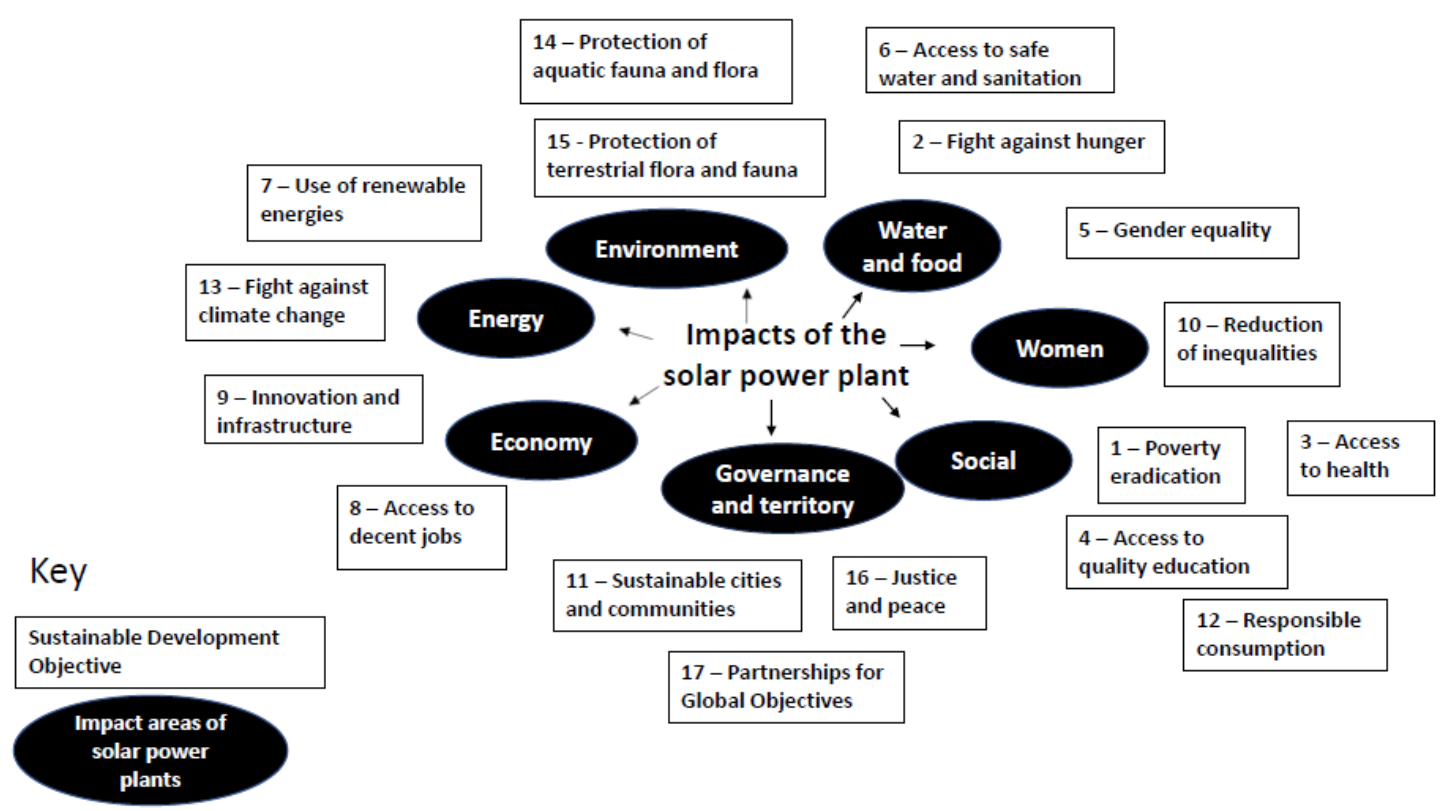

Figure 7. Overview of the indicators identified for the case study according to the areas of intervention of the Sustainable Development Goals (SDGs). 
Table 8. Major impacts of the PV Power Plant and the SDGs.

\begin{tabular}{|c|c|c|c|}
\hline & $\begin{array}{c}\text { The Solar Power Plant Supports or } \\
\text { Contributes }\end{array}$ & $\begin{array}{c}\text { The Solar Power Plant Supports or } \\
\text { Does Not Contribute }\end{array}$ & $\begin{array}{l}\text { Reason for Impairment or } \\
\text { Non-Contribution }\end{array}$ \\
\hline \multirow{4}{*}{ International Level } & SDG 13-Climate action & \multirow{4}{*}{$\begin{array}{l}\text { SDG 9-Industry, innovation and } \\
\text { infrastructure }\end{array}$} & \multirow{4}{*}{ Importation of most of the equipment } \\
\hline & $\begin{array}{c}\text { SDG 9-Industry, innovation and } \\
\text { infrastructure (promoting } \\
\text { the investments of a private operator) }\end{array}$ & & \\
\hline & $\begin{array}{l}\text { SDG 8-Decent work and economic } \\
\text { growth }\end{array}$ & & \\
\hline & SDG 7-Clean and affordable energy & & \\
\hline \multirow{4}{*}{ National Level } & $\begin{array}{l}\text { SDG 11- Sustainable cities and } \\
\text { communities }\end{array}$ & $\begin{array}{l}\text { SDG 9-Industry, innovation and } \\
\text { infrastructure }\end{array}$ & $\begin{array}{l}\text { Non-encouragement of a PV market, } \\
\text { environmental and social impact study } \\
\text { results were not made public, } \\
\text { centralization of decisions and } \\
\text { information relating to the plant }\end{array}$ \\
\hline & $\begin{array}{c}\text { SDG 9-Industry, innovation and } \\
\text { infrastructure (building national } \\
\text { expertise) }\end{array}$ & & \\
\hline & $\begin{array}{l}\text { SDG 8-Decent work and economic } \\
\text { growth }\end{array}$ & & \\
\hline & SDG 7-Clean and affordable energy & & \\
\hline \multirow{4}{*}{ Regional Level } & $\begin{array}{l}\text { SDG 11- Sustainable cities and } \\
\text { communities }\end{array}$ & SDG 7-Affordable and clean energy & $\begin{array}{l}\text { The production of the plant does not } \\
\text { correspond to peak consumption, } \\
\text { repercussions of intermittent production } \\
\text { on the electricity grid }\end{array}$ \\
\hline & $\begin{array}{l}\text { SDG 9-Industry, innovation and } \\
\text { infrastructure }\end{array}$ & SDG 6-Clean water and sanitation & $\begin{array}{c}\text { Development of polluting industries } \\
\text { using energy generated by the power } \\
\text { plant }\end{array}$ \\
\hline & $\begin{array}{l}\text { SDG 8-Decent work and economic } \\
\text { growth }\end{array}$ & & \\
\hline & SDG 7-Clean and affordable energy & & \\
\hline
\end{tabular}


Table 8. Cont.

\begin{tabular}{|c|c|c|c|}
\hline & $\begin{array}{c}\text { The Solar Power Plant Supports or } \\
\text { Contributes }\end{array}$ & $\begin{array}{c}\text { The Solar Power Plant Supports or } \\
\text { Does Not Contribute }\end{array}$ & $\begin{array}{l}\text { Reason for Impairment or } \\
\text { Non-Contribution }\end{array}$ \\
\hline \multirow{7}{*}{ Local Level } & $\begin{array}{l}\text { SDG 16-Peace, justice and strong } \\
\text { institutions (fees paid to the commune) }\end{array}$ & SDG 15-to be confirmed & Impact of night light on biodiversity \\
\hline & SDG 15-Life on land (trees preserved) & SDG 10-Reducing inequalities & $\begin{array}{l}\text { Inequalities between households with } \\
\text { electricity and those without }\end{array}$ \\
\hline & $\begin{array}{l}\text { SDG 11- Sustainable cities and } \\
\text { communities }\end{array}$ & $\begin{array}{l}\text { SDG 8-Decent work and economic } \\
\text { growth }\end{array}$ & $\begin{array}{c}\text { No impact on income-generating } \\
\text { activities }\end{array}$ \\
\hline & $\begin{array}{l}\text { SDG 8-Decent work and economic } \\
\text { growth (job creation) }\end{array}$ & SDG 7-Affordable and clean energy & Not available for local residents \\
\hline & $\begin{array}{l}\text { SDG 9-Industry, innovation and } \\
\text { infrastructure }\end{array}$ & $\begin{array}{l}\text { SDG 6-Clean water and sanitation } \\
\text { (impact to be confirmed) }\end{array}$ & \\
\hline & SDG 7-Clean and affordable energy & SDG 5-Gender equality & $\begin{array}{c}\text { Women's well-being affected or not } \\
\text { support }\end{array}$ \\
\hline & $\begin{array}{l}\text { SDG 3-Good health and well-being for } \\
\text { people (night light and security) }\end{array}$ & $\begin{array}{l}\text { SDGs } 1 / 2 / 3-\text { no poverty, zero hunger, } \\
\text { good health and well-being for people }\end{array}$ & $\begin{array}{l}\text { Fertile area that could be used for } \\
\text { cultivation, roads in poor condition, } \\
\text { limited employment }\end{array}$ \\
\hline
\end{tabular}




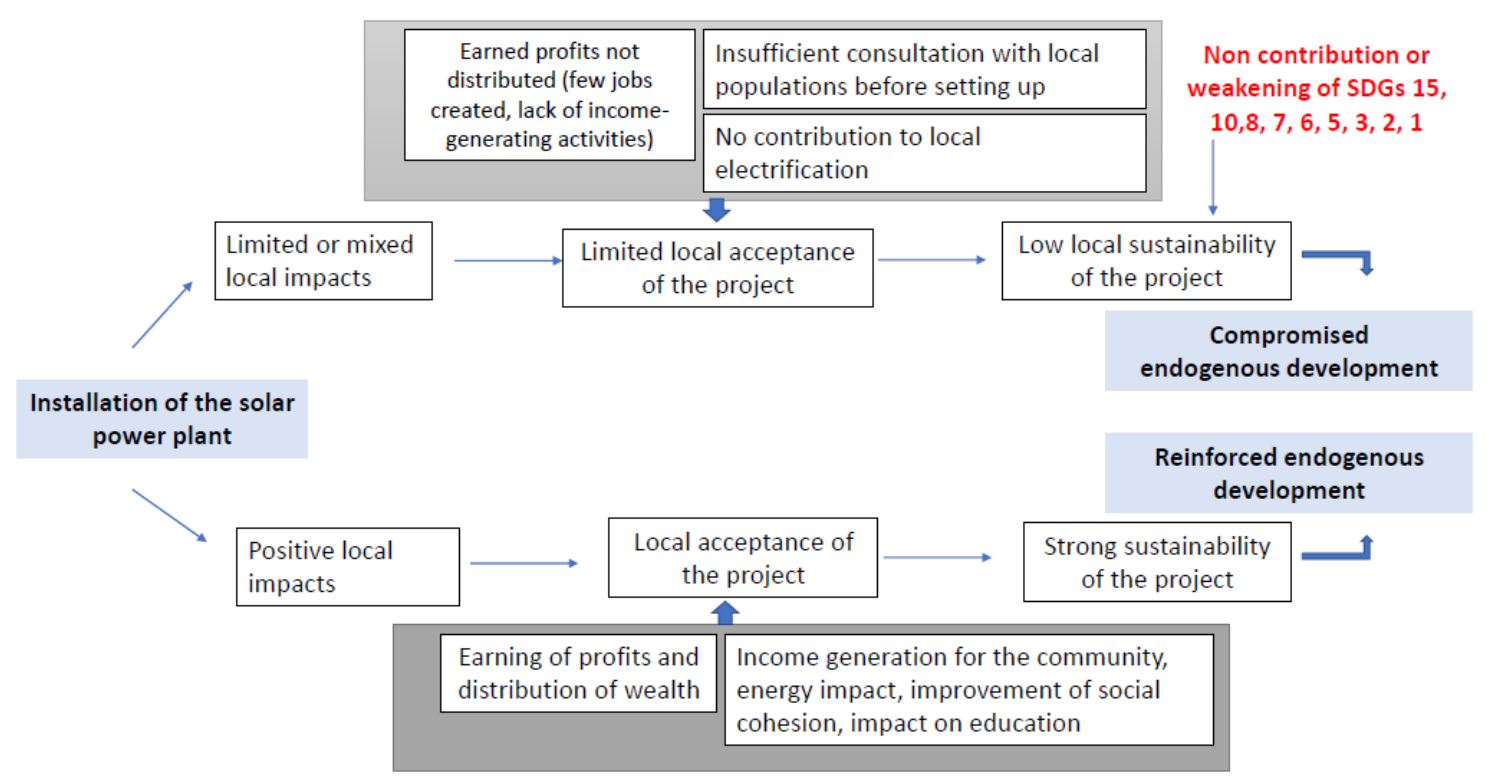

Figure 8. Analysis of the theory of endogenous development [107] applied to this case study.

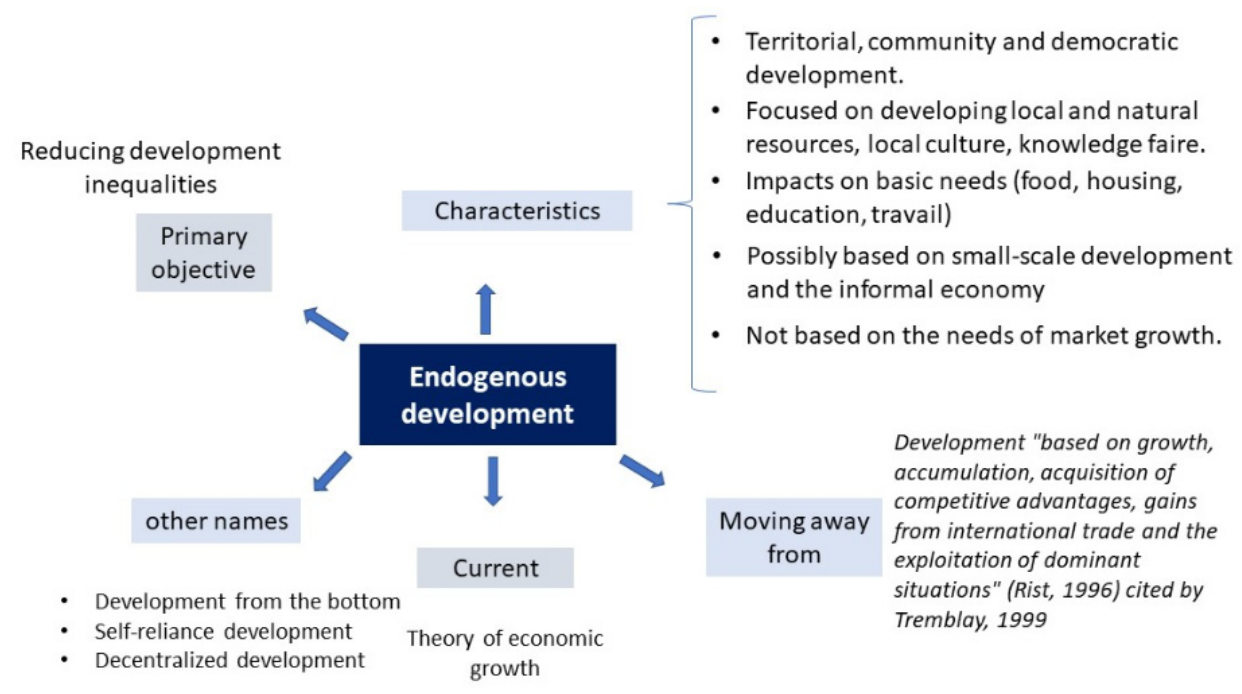

Figure 9. Brief overview of the theory of endogenous development. Source [110].

\subsection{Recommendations}

These recommendations attempt to make an "integrated" link between policy, investment, and energy access since they concern the main players and areas affected by the presence of the solar power plant. This is a first step towards stimulating the sustainability of the Plant by taking into account the challenges posed by the weakening of the SDGs. All levels are concerned (local, national, and international) bearing in mind that carrying out a strategic environmental assessment seems to be a priority. These recommendations take into account the wishes of the stakeholders interviewed, although the electrification of the plant's location area remains a recurring request from local communities.

From a practical point of view, several recommendations described in Table 9 are to be formulated to improve the sustainability of the plant. 
Table 9. Summary of practical recommendations.

\begin{tabular}{ccc}
\hline & Recommendations & Implementation of \\
Overall approach & $\begin{array}{c}\text { Strategic environmental assessment } \\
\text { integrating locally appropriate energy } \\
\text { coverage }\end{array}$ & Government \\
\hline Local level & $\begin{array}{c}\text { Implementation of a strategic social plan } \\
\text { Improvement of access roads } \\
\text { Monitoring water consumption } \\
\text { Use of IDA (International Dark Sky } \\
\text { Reserve) standard * }\end{array}$ & Power plant \\
\hline National level & $\begin{array}{c}\text { Gender policy adapted to on-grid RE } \\
\text { investments }\end{array}$ & \\
\hline & $\begin{array}{c}\text { Rural electrification policy linked to on grid } \\
\text { RE installations } \\
\text { Provision of environmental and energy data } \\
\text { Creation of a meteorological data network } \\
\text { International level }\end{array}$ & Government \\
& $\begin{array}{c}\text { Implation of the IDA standard * } \\
\text { the African continent, especially regarding } \\
\text { local development [111,112] } \\
\text { Anticipation of a circular economy strategy }\end{array}$ & Government \\
\hline${ }^{*}$ In order to alleviate power plant night light's impact on the biodiversity (see Table 8, local impacts).
\end{tabular}

From a theoretical point of view, we believe that the evaluation of the sustainability of solar power plants in a context of energy and socioeconomic poverty should follow an approach that: (i) envisages a methodology (preferably qualitative) capable of taking into account local conditions as close as possible to the communities in which they are installed; (ii) identifies dissociated indicators, taking into account the context of installation, which is at the heart of the concerns of stakeholders; and (iii) analyzes the possible interactions and negative correlations between the impact areas like in the priorities set by the SDGs while highlighting the key areas linked to land management and the well-being of women in determining an approach to fight against poverty [52].

The methodology presented in this work can easily be translated to other developing countries. As mentioned in paragraph 2, identical research was carried out in five other countries of the African continent with similar results, which is in the process of being published. In all cases, tensions between SDGs appear, which may call into question the endogenous development based on large scale solar PV power plants.

\section{Conclusions}

In a context of energy transition towards renewable energies, this case study allows us to verify the extent to which the presence of the photovoltaic solar power plant represents a vector for sustainable development in strategy for energy security and poverty reduction. We found that compared to the regional, national, and international levels, the most significant impacts (in terms of frequency and magnitude) are found at the local level.

Basing on the problem statement of our study, the lessons learned are as follows: (i) the plant can only be a vector for sustainable development with the collaboration of stakeholders, which includes the communities living near the facility; (ii) social acceptance of the plant cannot be considered without taking into account the electrification needs at the local level, especially in a poor rural area; (iii) although the power plant is an energy system in its own right, its optimization depends on factors outside of its control (cloud cover, operation, and quality of the electrical grid); (iv) although the power plant is based on renewable energy, the use of the electricity it produces does not exclude the generation 
of polluting activities; and (v) by downplaying the regional level of its impacts and the improvement of the situation of women at the local level, the plant loses the opportunity to strengthen its sustainability. This article proposes an adapted theoretical model for the evaluation of the sustainability of a PV solar plant. It identifies possible conflicts that may arise between the different the SDGs. These findings contradict the theory of endogenous development which considers renewable energies as a systematic vector for local development.

The results obtained in the framework of our research should encourage prudent policy decisions by way of the development of renewable energies. Indeed, the fight against climate change is a priority, and this fight requires a drastic reduction in our carbon emissions. However, although based on natural elements such as the sun, the wind or the tide, these green energies require fully-fledged technological systems whose complexity of impacts cannot be underestimated.

Author Contributions: Conceptualization, C.B.; methodology, C.B., C.C., C.G., N.M.; validation, O.S., P.B. and M.A.B.; formal analysis, C.B., O.S., P.B., M.A.B.; investigation, J.C.R., A.R.; resources, J.C.R., A.R.; data curation, C.B., M.A.B.; writing - original draft preparation, C.B.; writing-review and editing, C.B., O.S., P.B., M.A.B., C.C., C.G., N.M.; supervision, O.S.; project administration, C.B., M.A.B.; funding acquisition, P.B. All authors have read and agreed to the published version of the manuscript.

Funding: This article was funded by IDRC (International Development Research Centre-project no 108838-029), Polytechnic Montreal, the Trottier Institute of Energy, and the Social Sciences and Humanities Research Council of Canada (SSHRC)—Grant752 20172020.

Acknowledgments: Thanks to A. Langley et B. Sinclair-Desgagné (HEC Montreal), J. Rancourt (UQAM); in Madagascar thanks to ONE and the MEEH (Ministry of Water, Energy and Hydrocarbons), O. Nirina Ranaivosoa, and all the participants located in the Vakinankaratra Region.

Conflicts of Interest: The authors declare no conflict of interest.

\section{Appendix A}

Sustainability
Science
"research area as
combining work in
the area of
environmental
science with work in
economic, social and
development
studies to better
understand the
complex dynamic
interactions
between
environmental, social
and economic issues"
Kasemir, 2003 cited
by Ness, 2007

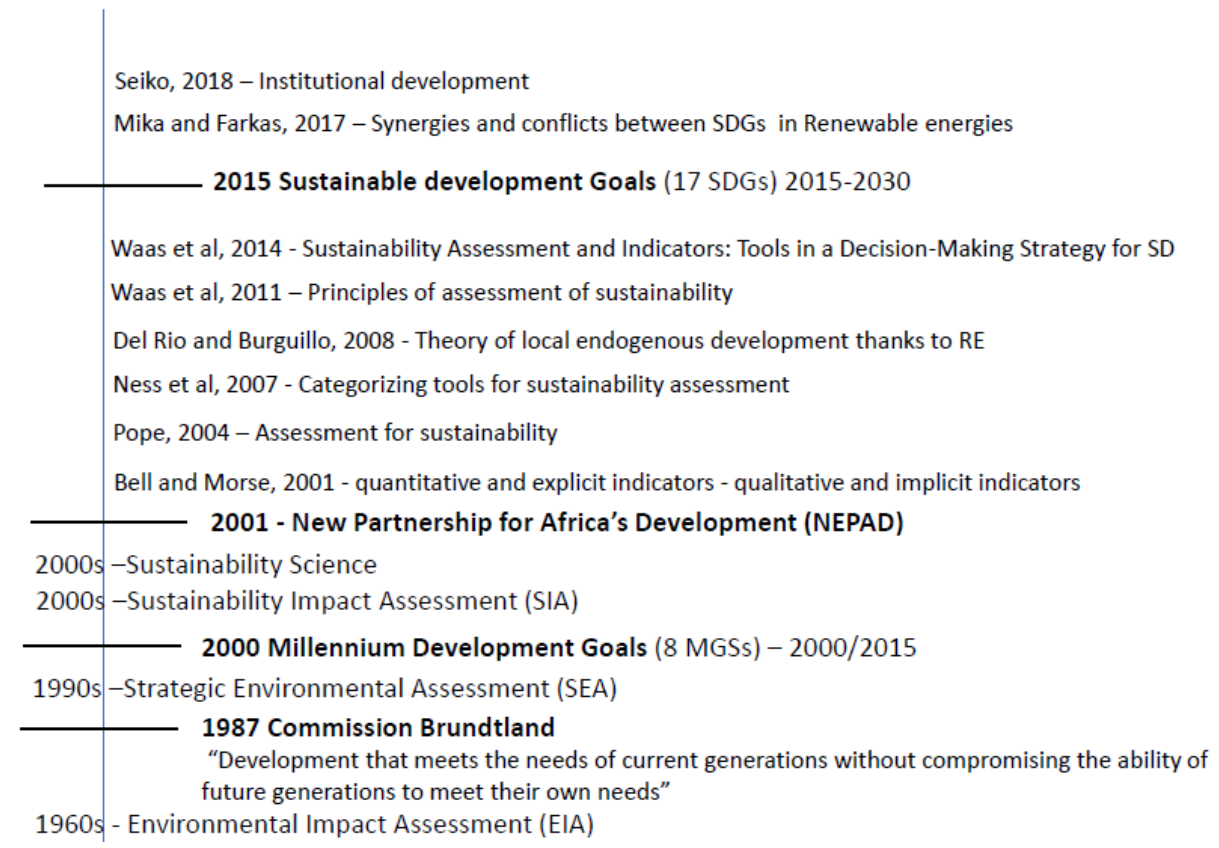

Figure A1. Historical framework of research-Sustainability science. 


\section{Positive impacts}

Economical

Social

Environmenta

Energetic

Water and Food

Governance and territory

Women

Economical

Social

Environmental

Energetic

Water and Food

Governance and territory

Women

Economical

Social

Environmental

Energetic

Water and Food

Governance and territory

Women

Economical

Social

Environmental

Energetic

Water and Food

Governance and territory Women
INTERNATIONAL IMPACTS

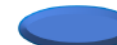

NATIONAL IMPACTS

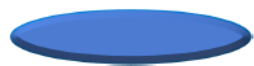

REGIONAL IMPACTS
Impacts to be improved

Economical

Social

Environmental

Energetic

Water and Food

Governance and territory

Women

Economical

Social

Environmental

Energetic

Water and Food

Governance and territory

Women

Economical

Social

Environmental

Energetic

Water and Food

Governance and territory

Women

Economical

Social

Environmental

Energetic

Water and Food

Governance and territory Women

Figure A2. List and typology of impacts used in this study.

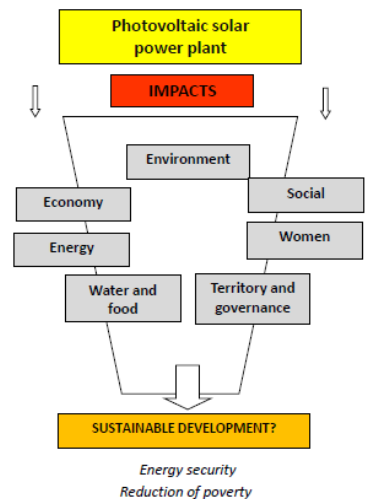

Figure A3. The conceptual approach of the study.

Table A1. Summary of economic impacts at the local level.

\begin{tabular}{lcl}
\hline & Economic Impacts \\
\hline & Local Level & \\
\hline Positive Aspects & Negative Aspects \\
\hline
\end{tabular}

- Creation of jobs during construction (around 300);

- $\quad$ Creation of jobs during construction (5 permanent and 7 temporary jobs and 12 security personnel);

- Majority of the employees living in the commune, which generates income for traders (with higher staff salaries);

- Improvement of workers' purchasing power;

- Payment of compensation to the commune;

- Developed and well-lit road securing economic exchanges (harvests transported securely);

- Contract with a (local) security company;

- Power plant participates in opening up the town (improved telephone network).
- Recruitment of construction staff questioned by local residents (non-transparency of the process);

- Limited number of jobs during operation;

- Little labor used considering the scope of the project and the low cost of local labor;

- No income-generating activities resulting from the presence of the power plant;

- $\quad$ Failure to fix roads around the plant. Only the road leading to the power plant has been developed. It is an unpaved road;

- $\quad$ Limited collaboration with local businesses;

- Little equipment from the locality;

- Land use competes with possible agricultural use (even if there is land available nearby);

- Low impact on the rural-urban migration. 
Table A2. Summary of social impacts at local level.

\begin{tabular}{ccc}
\hline & Social Impacts & \\
\hline & Local Level & \\
\hline Positive Aspects & Negative Aspects \\
\hline
\end{tabular}

- Distance of the site from residences (low-traffic area);

- $\quad$ Very protected site (but contributes to isolation) with improved safety for residents, especially at night;

- Improved telephone network;

- Donations to residents and schools;

- Grass cover between panels offered to residents free of charge;

- Raising awareness of local residents about large-scale solar energy;

- $\quad$ Presence of the plant source of pride due to good reputation of the commune and

the Fokontanys concerned;

- Encouragement of self-training for managers;

- Overall positive working conditions for managers (salary level, social insurance, transport).
- $\quad$ Limited social acceptance; low appropriation by residents;

- Risk of conflicts of interest (the power plant does its own assessment of its social responsibility);

- $\quad$ Nonexistent social strategy plan, limited donations, social relations to be consolidated with local populations;

- Non optimal quantity/quality of public consultations prior to construction;

- Frustrations with respect to promises made before construction (extension of the network, electricity with an adjusted cost, etc.);

- $\quad$ Non-transparent recruitment during construction (according to local residents) and tensions between local residents and temporary employees from the capital;

- $\quad$ Power plant staff requirements (for public relations with residents and energy optimization);

- Isolation of the site from its social environment;

- Limited encouragement of the use of off-grid equipment ( $\mathrm{PV}$ is given to schools, then stolen, not replaced);

- Narrow rooms for staff needs;

- No effective training in the field of PV (the staff is specialized in electricity but not in PV);

- No health unit available nearby (or inside) the facilities;

- Absence of significant impact on the family situation of people located nearby and schools/health units;

- Impact of dust on the health of residents due to the laterite road;

- Difficult working conditions for security staff in watchtowers (cold, standing) and managerial staff (on-call conditions at weekends, working time);

- In the event of serious incidents, firefighters located in the Antsirabe barracks which is $2 \mathrm{hrs}-1 \mathrm{hr} 30$ drive from the power plant.

Table A3. Summary of impacts on the environment at local level.

\begin{tabular}{lll}
\hline \multicolumn{3}{c}{ Impacts on the Environment } \\
\hline \multicolumn{2}{c}{ Local Level } \\
\hline Positive Aspects & Negative Aspects \\
\hline
\end{tabular}

- Contributes to the reduction of $\mathrm{CO}_{2}$ emissions $(24,000 \mathrm{~T}$ of $\mathrm{CO}_{2}$ avoided per year);

- No visible, noise, or smell pollution;

- Limited deforestation;

- No significant impact on flora and fauna;

- No chemical fertilizers or weed killers used;

- No modification of the soil/no aggressive earthworks (terrain is generally flat);

- No electrical barrier for animal fauna;

- Attempt to use animals (sheep) for removing the grass;

- Clean site (no packaging, trash, visible waste);

- To be confirmed: recycling of equipment at the end of life or during operation (possible return to China);

- Contributes to reducing the need to build hydropower stations which have a more significant environmental and social impact.

- $\quad$ Air pollution (due to dust from the roads and the transport of the plant's management staff);

- Possible impact of light on the site's nightlife (local flora and fauna);

- Construction waste not disposed in an appropriate site (used by residents) - but no recycling site in Madagascar. 
Table A4. Summary of energy impacts at local level.

\begin{tabular}{|c|c|}
\hline \multicolumn{2}{|c|}{ Energy Impacts } \\
\hline \multicolumn{2}{|c|}{ Local Level } \\
\hline Positive Aspects & Negative Aspects \\
\hline $\begin{array}{l}\text { - Local energy impact but only } \\
\text { for people already connected } \\
\text { to the grid; } \\
\text { Reduction of power cuts for } \\
\text { the majority of people, since } \\
\text { the installation of the plant. }\end{array}$ & $\begin{array}{l}\text { Power plant's production intended } \\
\text { only for the national grid without } \\
\text { direct distribution at the local level; } \\
\text { Production of the power plant not } \\
\text { allowing an extension of rural } \\
\text { electrification in the Fokontany where } \\
\text { it is located, for people not connected } \\
\text { to the grid; } \\
\text { - Another geographic setting of the site } \\
\text { (with better sunshine) could have } \\
\text { enabled production optimization; } \\
\text { - Lack of energy storage; } \\
\text { Electricity produced by the plant } \\
\text { neither used nor stored (in the event of } \\
\text { a breakdown in the national electricity } \\
\text { grid); } \\
\text { Rationalization of off grid systems } \\
\text { given to schools by the power plant } \\
\text { (flights, maintenance). }\end{array}$ \\
\hline
\end{tabular}

Table A5. Summary of impacts on water and food at local level.

\begin{tabular}{cl}
\hline \multicolumn{1}{c}{ Impacts on Water and Food } \\
\hline \multicolumn{1}{c}{ Local Level } \\
\hline \multicolumn{1}{c}{ Positive Aspects } & \multicolumn{1}{c}{ Negative Aspects } \\
\hline \multicolumn{1}{c}{$\begin{array}{l}\text { No significant negative impact on } \\
\text { access to water (the plant has only } \\
\text { had 1 PV cleaning in one year of } \\
\text { existence). }\end{array}$} & $\begin{array}{l}\text { Lack of data on the amount } \\
\text { of water used to operate } \\
\text { the power plant; } \\
\text { Water available in the plant } \\
\text { not shared with } \\
\text { local residents. }\end{array}$
\end{tabular}

\section{Food}

- $\quad$ Light given off by the power plant at night allows more secure access to food resources;

- $\quad$ Power plant can reduce the need for building hydropower plant which has a more significant environmental and social impact;

- Grass cover between the panels given free to residents.
- $\quad$ Fertility of the area occupied by the plant could be used for local agriculture;

- Risk of deterioration of food security in the future due to roads not built for agricultural machinery. 
Table A6. Summary of impacts on governance and land at local level.

\begin{tabular}{|c|c|}
\hline \multicolumn{2}{|c|}{ Impacts on Governance and Land } \\
\hline \multicolumn{2}{|c|}{ Local Level } \\
\hline Positive Aspects & Negative Aspects \\
\hline \multicolumn{2}{|c|}{ Governance } \\
\hline $\begin{array}{l}\text { Relationships developed with } \\
\text { the Fokontany; } \\
\text { Payment of a fee to } \\
\text { the commune administration. }\end{array}$ & $\begin{array}{l}\text { - Little consultation with local } \\
\text { populations before installing } \\
\text { the plant; } \\
\text { - Doubt about the right } \\
\text { amount of fee to be paid to } \\
\text { the commune. }\end{array}$ \\
\hline \multicolumn{2}{|c|}{ Land } \\
\hline $\begin{array}{l}\text { Value of the land around the power } \\
\text { plant has not changed; } \\
\text { - No conflict over land ownership; } \\
\text { - Landscape looks more attractive. }\end{array}$ & $\begin{array}{l}\text { - Access roads partially in poor } \\
\text { condition, unfavorable for } \\
\text { local communities. }\end{array}$ \\
\hline
\end{tabular}

Table A7. Summary of impacts on women at local level.

\begin{tabular}{|c|c|}
\hline \multicolumn{2}{|c|}{ Impacts on Women } \\
\hline \multicolumn{2}{|c|}{ Local Level } \\
\hline Positive Aspects & Negative Aspects \\
\hline $\begin{array}{l}\text { - Employment of women by the Plant (2 } \\
\text { of the } 13 \text { employees are women); } \\
\text { - Willingness: "we tried to hire a female } \\
\text { cook in the plant". }\end{array}$ & $\begin{array}{l}\text { - Women's jobs in the plant are temporary and for } \\
\text { the unskilled; } \\
\text { Low impact on women in general, especially } \\
\text { those residing around the plant: no health center } \\
\text { nearby, education of children, etc.; } \\
\text { - Frustration of women who received insufficient } \\
\text { donations compared to the need (e.g., in schools, } \\
\text { where some are volunteers); } \\
\text { Impact on food security (poor condition of roads } \\
\text { to transport crops). }\end{array}$ \\
\hline
\end{tabular}

Table A8. Nomenclature table with units.

\begin{tabular}{cccc}
\hline Electrical Parameter & Meaning & Metric Unit & Symbol \\
\hline Power & $\begin{array}{c}\text { Ability-potential } \\
\text { The rate at which } \\
\text { work is done. }\end{array}$ & $\begin{array}{c}\text { Watts } \\
\text { Kilowatts } \\
\text { Megawatts }\end{array}$ & $\begin{array}{c}\mathrm{kW}(=1000 \text { watts }) \\
\mathrm{MW}(=1,000,000 \text { watts })\end{array}$ \\
$\begin{array}{c}\text { Energy } \\
\begin{array}{c}\text { Power used over a period } \\
\text { of time multiplied by } \\
\text { duration of use }\end{array}\end{array}$ & $\begin{array}{c}\text { How much energy } \\
\text { used }\end{array}$ & $\begin{array}{c}\text { Watt-hours } \\
\text { Kilowatt-hours } \\
\text { Megawatt-hours }\end{array}$ & $\begin{array}{c}\text { MWh }(=1,000,000 \mathrm{Wh}) \\
\text { Energy (kWh) }=\text { power } \\
(\mathrm{kW}) \times \text { time used (h) }\end{array}$ \\
\hline
\end{tabular}




\section{References}

1. Lights, Power, Action; Africa Progress Panel: Geneva, Switzerland. 2016. Available online: https://www.africa50.com/fileadmin/uploads/africa50/Documents/Knowledge_Center/APP_Light s_Power_Action_2016__PDF.pdf (accessed on 1 March 2020).

2. IRENA. Africa 2030: Roadmap for a Renewable Energy Future; IRENA: Abu Dhabi, UAE, 2015; Available online: https:/www.irena.org/-/media/Files/IRENA/Agency/Publication/2015/IRENA_Africa_2030_REma p_2015_low-res.pdf (accessed on 1 March 2020).

3. Rapport Annuel 2018-Vers un Développement Durable Basé sur une Transition Démocratique; PNUD Madagascar: Antananarivo. 2018. Available online: https://www.mg.undp.org/content/madagascar/fr/home /library/mdg/rapport-annuel-2018---pnud-madagascar---vers-un-developpement-du.html (accessed on 1 March 2020).

4. Poorest Countries in Africa 2020. World Population Review. 2020. Available online: https://worldpopulationr eview.com/country-rankings/poorest-countries-in-africa (accessed on 9 September 2020).

5. Brunet, C.; Savadogo, O.; Baptiste, P.; Bouchard, M.A. Shedding some light on photovoltaic solar energy in Africa-A literature review. Renew. Sust. Energ. Rev. 2018, 96, 325-342. [CrossRef]

6. Bawakyillenuo, S. Deconstructing the dichotomies of solar photovoltaic (PV) dissemination trajectories in Ghana, Kenya and Zimbabwe from the 1960s to 2007. Energy Policy 2012, 49, 410-421. [CrossRef]

7. Mala, K.; Schläpfer, A.; Pryor, T. Better or worse? The role of solar photovoltaic (PV) systems in sustainable development: Case studies of remote atoll communities in Kiribati. Renew. Energy 2009, 34, 358-361. [CrossRef]

8. Chaurey, A.; Kandpal, T.C. Assessment and evaluation of PV based decentralized rural electrification: An overview. Renew. Sust. Energ. Rev. 2010, 14, 2266-2278. [CrossRef]

9. Rahman, M.M.; Paatero, J.V.; Lahdelma, R. Evaluation of choices for sustainable rural electrification in developing countries: A multicriteria approach. Energy Policy 2013, 59, 589-599. [CrossRef]

10. Karekezi, S.; Kithyoma, W. Renewable energy strategies for rural Africa: Is a PV-led renewable energy strategy the right approach for providing modern energy to the rural poor of sub-Saharan Africa? Energy Policy 2002, 30, 1071-1086. [CrossRef]

11. Mandelli, S.; Barbieri, J.; Mereu, R.; Colombo, E. Off-grid systems for rural electrification in developing countries: Definitions, classification and a comprehensive literature review. Renew. Sust. Energ. Rev. 2016, 58, 1621-1646. [CrossRef]

12. Martinot, E.; Cabraal, A.; Mathur, S. World Bank/GEF solar home system projects: Experiences and lessons learned 1993-2000. Renew. Sust. Energ. Rev. 2001, 5, 39-57. [CrossRef]

13. Nfah, E.M. Evaluation of optimal photovoltaic hybrid systems for remote villages in Far North Cameroon. Renew. Energy 2013, 51, 482-488. [CrossRef]

14. Nieuwenhout, F.D.J.; van Dijk, A.; Lasschuit, P.E.; van Roekel, G.; van Dijk, V.P.A.; Hirsch, D.; Arriaza, H.; Hankins, M.; Sharma, B.D.; Wade, H. Experience with solar home systems in developing countries: A review. Prog. Photovolt. 2001, 9, 455-474. [CrossRef]

15. Nkwetta, D.N.; Smyth, M.; Van Thong, V.; Driesen, J.; Belmans, R. Electricity supply, irregularities, and the prospect for solar energy and energy sustainability in Sub-Saharan Africa. J. Renew. Sustain. Ener. 2010, 2, 023102. [CrossRef]

16. Akinyele, D.O.; Rayudu, R.K.; Nair, N.K.C. Global progress in photovoltaic technologies and the scenario of development of solar panel plant and module performance estimation-Application in Nigeria. Renew. Sust. Energ. Rev. 2015, 48, 112-139. [CrossRef]

17. Hanger, S.; Komendantova, N.; Schinke, B.; Zejli, D.; Ihlal, A.; Patt, A. Community acceptance of large-scale solar energy installations in developing countries: Evidence from Morocco. Energy Res. Soc. Sci. 2016, 14, 80-89. [CrossRef]

18. Baurzhan, S.; Jenkins, G.P. Off-grid solar PV: Is it an affordable or appropriate solution for rural electrification in Sub-Saharan African countries? Renew. Sust. Energ. Rev. 2016, 60, 1405-1418. [CrossRef]

19. Stoms, D.M.; Dashiell, S.L.; Davis, F.W. Siting solar energy development to minimize biological impacts. Renew. Energy 2013, 57, 289-298. [CrossRef] 
20. Torres-Sibille, A.d.C.; Cloquell-Ballester, V.-A.; Cloquell-Ballester, V.-A.; Artacho Ramirez, M.Á. Aesthetic impact assessment of solar power plants: An objective and a subjective approach. Renew. Sust. Energ. Rev. 2009, 13, 986-999. [CrossRef]

21. Rodrigues, M.; Montañés, C.; Fueyo, N. A method for the assessment of the visual impact caused by the large-scale deployment of renewable-energy facilities. Environ. Impact Assess. Rev. 2010, 30, 240-246. [CrossRef]

22. Kaundinya, D.P.; Balachandra, P.; Ravindranath, N.H. Grid-connected versus stand-alone energy systems for decentralized power-A review of literature. Renew. Sust. Energ. Rev. 2009, 13, 2041-2050. [CrossRef]

23. Eltawil, M.A.; Zhao, Z. Grid-connected photovoltaic power systems: Technical and potential problems-A review. Renew. Sust. Energ. Rev. 2010, 14, 112-129. [CrossRef]

24. Cabrera-Tobar, A.; Bullich-Massagué, E.; Aragüés-Peñalba, M.; Gomis-Bellmunt, O. Review of advanced grid requirements for the integration of large scale photovoltaic power plants in the transmission system. Renew. Sust. Energ. Rev. 2016, 62, 971-987. [CrossRef]

25. Yenneti, K.; Day, R.; Golubchikov, O. Spatial justice and the land politics of renewables: Dispossessing vulnerable communities through solar energy mega-projects. Geoforum 2016, 76, 90-99. [CrossRef]

26. Stock, R.; Birkenholtz, T. The sun and the scythe: Energy dispossessions and the agrarian question of labor in solar parks. J. Peasant Stud. 2019, 1-24. [CrossRef]

27. World Bank Group. Global Solar Atlas. Available online: https://olc.worldbank.org/content/global-solar-atlas (accessed on 1 March 2020).

28. Kasemir, B.; Jaeger, C.C.; Jager, J. Citizen Participation in Sustainability Assessments. In Public Participation in Sustainability Science: A Handbook; Cambridge University Press: Cambridge, UK, 2003; pp. 3-36. Available online: https://www.cambridge.org/core/books/public-participation-in-sustainability-science/E6EDFED0 D1F2A09A8123E0C31E40B907?_cf_chl_jschl_tk_=9ac74bb42f1e2baec58e3d3f881a430d3ba7415e-159935 7538-0-AfNeL-Mb3nZU12ATsjQIi5clN3fXhaQwU49xawdRALNeoj55Ukoerplemmv3XjrnyE7T4bx-u7o8c Eay7WyDIbZxYoncXwDTCZD3en6x3LfqNDnfXWf_uBUg2lVr5MbMLNSRIZzs2RO9HGoYUW-9wm9aQ RHoMcqvsBAVv6zL5Wt_7w19U9ZzJBltNKtViahFS95p60O-0Q-lvmpt8JE_dWLR7HdVc1icjnLNK5CLW6b SGRebBJLtCvmCYfmmS16IYMAoKrtx1c11pN9J9beXVpM0VKjsTv6uhfzi8fvmf0nCMQrX9sje8Ril6v9hLVt vF_FQXXAdu7oZ4oVZTC8sLWhg9LL9WT93_Ge_V5n6DbHv7nNEcE0i5r18c3_mpCBy3LCnzUmmGBPB6S4cpJnlim5F0UEtdEE4VoaroX_fzSvOuCv0D5Ry3v3vRYTZyoIXWre9Uov88jyrCIK614YQFQ (accessed on 1 March 2020).

29. Ancient Roots, New Shoots: Endogenous Development in Practice; Haverkort, B.; van't Hooft, K.; Hiemstra, W. (Eds.) Zed Books: London, UK, 2003; Available online: http://www.bibalex.org/Search4Dev/files/416885/3624 67.pdf (accessed on 1 March 2020).

30. Kates, R.W.; Clark, W.C.; Corell, R.; Hall, J.M.; Jaeger, C.C.; Lowe, I.; McCarthy, J.J.; Schellnhuber, H.J.; Bolin, B.; Dickson, N.M. Sustainability science. Science 2001, 292, 641-642. [CrossRef] [PubMed]

31. Wiek, A.; Ness, B.; Schweizer-Ries, P.; Brand, F.S.; Farioli, F. From complex systems analysis to transformational change: A comparative appraisal of sustainability science projects. Sustain. Sci. 2012, 7, 5-24. [CrossRef]

32. Lang, D.J.; Wiek, A.; Bergmann, M.; Stauffacher, M.; Martens, P.; Moll, P.; Swilling, M.; Thomas, C.J. Transdisciplinary research in sustainability science: Practice, principles, and challenges. Sustain. Sci. 2012, 7, 25-43. [CrossRef]

33. Pope, J.; Annandale, D.; Morrison-Saunders, A. Conceptualising sustainability assessment. Environ. Impact Assess. Rev. 2004, 24, 595-616. [CrossRef]

34. De Maio, J.L.; Scheld, S.; Woldeamanuel, M. Sustainability in Sub-Saharan Africa: Problems, Perspectives, and Prospects; Dendere, C., Dill, B., Khalil, H., Kyomugisha, F., Michaud, K., Nkulu-N'Sengha, M., Pope, B.D., Eds.; Rowman \& Littlefield, 2018. Available online: https://books.google.com.hk/books/about/Sustainability _in_Sub_Saharan_Africa.html?id=cGx8DwAAQBAJ\&redir_esc=y (accessed on 1 March 2020).

35. Seiko, Z.M. Theories and Practices of Sustainable Development in Africa. In Handbook of Research on Sustainable Development and Governance Strategies for Economic Growth in Africa; 2018; pp. 1-29. Available online: https:// www.igi-global.com/chapter/theories-and-practices-of-sustainable-development-in-africa/197581 (accessed on 1 March 2020). 
36. Gibson, R.B. Specification of Sustainability-Based Environmental Assessment Decision Criteria and Implications for Determining" Significance" in Environmental Assessment; Canadian Environmental Assessment Agency Ottawa. 2001. Available online: https://static.twoday.net/NE1BOKU0607/files/Gibson_ Sustainability-EA.pdf (accessed on 1 March 2020).

37. Waas, T.; Hugé, J.; Block, T.; Wright, T.; Benitez-Capistros, F.; Verbruggen, A. Sustainability assessment and indicators: Tools in a decision-making strategy for sustainable development. Sustainability 2014, 6, 5512-5534. [CrossRef]

38. Waas, T.; Hugé, J.; Verbruggen, A.; Wright, T. Sustainable development: A bird's eye view. Sustainability 2011, 3, 1637-1661. [CrossRef]

39. Gendron, C.; Revéret, J.-P. Sustainable development. Econ. Soc. 2000, 37, 111-124.

40. Drimie, S.; Mini, S. Food Security and Sustainable Development in Southern Africa; HSRC Press: Cape Town, South Africa, 2003; Volume 6, Available online: https://books.google.com.ph/books/about/Food_Security_an d_Sustainable_Developmen.html?id=4Ldiqt3e4ZoC\&redir_esc=y (accessed on 1 March 2020).

41. Kates, R.W.; Dasgupta, P. African poverty: A grand challenge for sustainability science. Proc. Natl. Acad. Sci. USA 2007, 104, 16747-16750. [CrossRef]

42. Riffon, O.; Villeneuve, C. Donner Voix aux Multiples Représentations du Développement Durable dans les Formations en Génie. Proc. Can. Eng. Educ. Assoc. (CEEA) 2013. Available online: https://www.researchgate.net/profile/Claude_Villeneuve/publication/315974574_DONNER_VOIX_AUX_ MULTIPLES_REPRESENTATIONS_DU_DEVELOPPEMENT_DURABLE_DANS_LES_FORMATIONS_E N_GENIE/links/5a6659a3a6fdccb61c5a75ac/DONNER-VOIX-AUX-MULTIPLES-REPRESENTATIONS-D U-DEVELOPPEMENT-DURABLE-DANS-LES-FORMATIONS-EN-GENIE.pdf (accessed on 1 March 2020). [CrossRef]

43. Riffon, O.; Villeneuve, C.; Une typologie du développement durable. Liaison Énergie Francoph. 2011. Available online: https:/constellation.uqac.ca/2451/1/Une_typologie_du_d\%C3\%A9veloppement_durable.p df (accessed on 1 March 2020).

44. Gasparatos, A.; Takeuchi, K.; Elmqvist, T.; Fukushi, K.; Nagao, M.; Swanepoel, F.; Swilling, M.; Trotter, D.; von Blottnitz, H. Sustainability science for meeting Africa's challenges: Setting the stage. Sustain. Sci. 2017, 12, 635-640. [CrossRef]

45. Obasi, G.O. Embracing Sustainability Science. The Challenges for Africa. Environ. Sci. Policy Sustain. Dev. 2002, 44, 8-19. [CrossRef]

46. Singh, R.K.; Murty, H.R.; Gupta, S.K.; Dikshit, A.K. An overview of sustainability assessment methodologies. Ecol. Indic. 2012, 15, 281-299. [CrossRef]

47. Bell, S.; Morse, S. Sustainability Indicators: Measuring the Immeasurable? 2nd ed.; Routledge: London, UK; New York, NY, USA, 2012; Available online: https://www.routledge.com/Sustainability-Indicators-Measurin g-the-Immeasurable-2nd-Edition/Bell-Morse/p/book/9781844072996 (accessed on 1 March 2020).

48. Bell, S.; Morse, S. Breaking through the glass ceiling: Who really cares about sustainability indicators? Local Environ. 2001, 6, 291-309. [CrossRef]

49. Ness, B.; Urbel-Piirsalu, E.; Anderberg, S.; Olsson, L. Categorising tools for sustainability assessment. Ecol. Econ. 2007, 60, 498-508. [CrossRef]

50. Reed, M.S.; Fraser, E.D.G.; Dougill, A.J. An adaptive learning process for developing and applying sustainability indicators with local communities. Ecol. Econ. 2006, 59, 406-418. [CrossRef]

51. Mori, K.; Christodoulou, A. Review of sustainability indices and indicators: Towards a new City Sustainability Index (CSI). Environ. Impact Assess. Rev. 2012, 32, 94-106. [CrossRef]

52. Pissourios, I.A. An interdisciplinary study on indicators: A comparative review of quality-of-life, macroeconomic, environmental, welfare and sustainability indicators. Ecol. Indic. 2013, 34, 420-427. [CrossRef]

53. Blanchet, D. La mesure de la soutenabilité. Revue de l'OFCE 2012, 120, 287-310. [CrossRef]

54. Stiglitz, J.E.; Sen, A.K.; Fitoussi, J.-P. Report by the Commission on the Measurement of Economic Performance and Social Progress, Paris, France. 2009. Available online: https://www.cpc.unc.edu/projects/rlms-hse/public ations/1921 (accessed on 1 March 2020).

55. Santoyo-Castelazo, E.; Azapagic, A. Sustainability assessment of energy systems: Integrating environmental, economic and social aspects. J. Clean. Prod. 2014, 80, 119-138. [CrossRef] 
56. Liu, G. Development of a general sustainability indicator for renewable energy systems: A review. Renew. Sust. Energy Rev. 2014, 31, 611-621. [CrossRef]

57. Iddrisu, I.; Bhattacharyya, S.C. Sustainable Energy Development Index: A multi-dimensional indicator for measuring sustainable energy development. Renew. Sust. Energy Rev. 2015, 50, 513-530. [CrossRef]

58. Feron, S. Sustainability of off-grid photovoltaic systems for rural electrification in developing countries: A review. Sustainability 2016, 8, 1326. [CrossRef]

59. Ilskog, E. Indicators for assessment of rural electrification-An approach for the comparison of apples and pears. Energy Policy 2008, 36, 2665-2673. [CrossRef]

60. Terrapon-Pfaff, J.; Dienst, C.; Ortiz, W. The role of gender concerns in the planning of small-scale energy projects in developing countries. In Decentralized Solutions for Developing Economies; Groh, S., van der Straeten, J., Edlefsen Lasch, B., Gershenson, D., Leal Filho, W., Kammen, D., Eds.; Springer: Cham, Switzerland, 2015; pp. 285-294.

61. Oparaocha, S.; Dutta, S. Gender and energy for sustainable development. Curr. Opin. Environ. Sustain. 2011, 3, 265-271. [CrossRef]

62. Clancy, J.S.; Skutsch, M.; Batchelor, S. The Gender-Energy-Poverty Nexus: Finding the Energy to Address Gender Concerns in Development. DFID Project CNTR998521 2003. Available online: https://esmap.org/si tes/default/files/resources-document/The\%20Gender\%20Energy\%20Poverty\%20Nexus.pdf (accessed on 1 March 2020).

63. Glemarec, Y.; Bayat-Renoux, F.; Waissbein, O. Removing barriers to women entrepreneurs' engagement in decentralized sustainable energy solutions for the poor. AIMS Energy 2016, 4, 136-172. [CrossRef]

64. Takeuchi, K.; Aginam, O. Sustainability challenges and opportunities in Africa. Sustain. Sci. 2011, 6, 3-5. [CrossRef]

65. Yadoo, A.; Cruickshank, H. The role for low carbon electrification technologies in poverty reduction and climate change strategies: A focus on renewable energy mini-grids with case studies in Nepal, Peru and Kenya. Energy Policy 2012, 42, 591-602. [CrossRef]

66. Jones, K.; Alexander, S.M.; Bennett, N.; Bishop, L.; Budden, A.; Cox, M.; Crosas, M.; Game, E.; Geary, J.; Hahn, C.; et al. Qualitative Data Sharing and Re-Use for Socio-Environmental Systems Research: A Synthesis of Opportunities, Challenges, Resources and Approaches. 2018. Available online: https://drum.lib.umd.edu /handle/1903/20257 (accessed on 1 March 2020).

67. Eisenhardt, K.M. Building theories from case study research. Acad. Manag. Rev. 1989, 14, 532-550. [CrossRef]

68. Ryan, G.W.; Bernard, H.R. Data management and analysis methods. In Handbook of Qualitative Research, 2nd ed.; Denzin, N.K., Lincoln, Y.S., Eds.; Sage Publications: Washington, DC, USA, 1994; Available online: https://utsc.utoronto.ca/ \{\}kmacd/IDSC10/Readings/Data\%20analysis/methods.pdf (accessed on 1 March 2020).

69. Yin, R.K. Case Study Research and Applications: Design and Methods, 6th ed.; Sage publications: Washington, DC, USA, 2017; Available online: https://www.amazon.com/Case-Study-Research-Applications-Methods/dp /1506336167 (accessed on 1 March 2020).

70. Yin, R.K. Case study methods. In APA Handbooks in Psychology ${ }^{\circledR}$. APA Handbook of Research Methods in Psychology; Cooper, H., Camic, P.M., Long, D.L., Panter, A.T., Rindskopf, D., Sher, K.J., Eds.; APA: Washington, DC, USA, 2012; Volume 2, pp. 141-155. Available online: https://psycnet.apa.org/record/2011-23864-009 (accessed on 1 March 2020).

71. Sovacool, B.K.; Axsen, J.; Sorrell, S. Promoting novelty, rigor, and style in energy social science: Towards codes of practice for appropriate methods and research design. Energy Res. Soc. Sci. 2018, 45, $12-42$. [CrossRef]

72. Anadón, M.; Guillemette, F. La recherche qualitative est-elle nécessairement inductive. Rech. Qual. 2006, 5, $26-37$.

73. Surroop, D.; Raghoo, P. Renewable energy to improve energy situation in African island states. Renew. Sust. Energy Rev. 2018, 88, 176-183. [CrossRef]

74. Surroop, D.; Raghoo, P.; Wolf, F.; Shah, K.U.; Jeetah, P. Energy access in Small Island Developing States: Status, barriers and policy measures. Environ. Dev. 2018, 27, 58-69. [CrossRef]

75. Dornan, M. Access to electricity in Small Island Developing States of the Pacific: Issues and challenges. Renew. Sust. Energy Rev. 2014, 31, 726-735. [CrossRef] 
76. Praene, J.P.; Radanielina, M.H.; Rakotoson, V.R.; Andriamamonjy, A.L.; Sinama, F.; Morau, D.; Rakotondramiarana, H.T. Electricity generation from renewables in Madagascar: Opportunities and projections. Renew. Sust. Energy Rev. 2017, 76, 1066-1079. [CrossRef]

77. Hammar, L.; Ehnberg, J.; Mavume, A.; Cuamba, B.C.; Molander, S. Renewable ocean energy in the Western Indian Ocean. Renew. Sust. Energy Rev. 2012, 16, 4938-4950. [CrossRef]

78. IME. Structure de la Consommation d'Énergie à Madagascar. Available online: https://www.ime.mg/actus/s tructure-de-la-consommation.html (accessed on 1 March 2020).

79. Investment Plan for Renewable Energy in Madagascar; Ministry Of Water, Energy and Hydrocarbons: Antananarivo, Madagascar, 2018; Available online: https:/www.climateinvestmentfunds.org/sites/cif_enc/fil es/srepinvestment_plan_for_madagascar_final.pdf (accessed on 1 March 2020).

80. LA BANQUE MONDIALE. La Force du Soleil. Madagascar se Lance dans la Production d'Énergie Renouvelable. Available online: https://www.banquemondiale.org/fr/news/feature/2018/10/10/the-force-of- $t$ he-sun-madagascar-embarks-on-renewable-energy-production (accessed on 1 March 2020).

81. Antanarivo University. Pourquoi Madagascar reste pauvre malgré sa forte potentialité économique? Available online: https:/www.ime.mg/actus/energie-renouvelables.html (accessed on 1 March 2020).

82. Praene, J.P.; Radanielina, M.H.; Rakotondramiarana, H.T. Dish stirling system potential assessment for eight main sites in Madagascar. JP J. Heat Mass Transf. 2016, 13, 119-141. [CrossRef]

83. De Souza, O. Madagascar: Trois Projets Solaires Seront installés avant la fin de cette Année. Agence Ecofin 2019. Available online: https://www.agenceecofin.com/solaire/2606-67321-madagascar-trois-projets-solairesseront-installes-avant-la-fin-de-cette-annee (accessed on 1 March 2020).

84. Fondation Énergies pour le Monde. De l’Électricité Verte pour un Million de Ruraux à Madagascar. Available online: http://www.fondem.ong/pdf/publication/Fondem-Brochure-Noria-Madagascar-2010.pdf (accessed on 1 March 2020).

85. IRENA. Renewable Capacity Highlights. 2019. Available online: https://www.irena.org/-/media/Files/IREN A/Agency/Publication/2020/Mar/IRENA_RE_Capacity_Highlights_2020.pdf?la=en\&hash=B6BDF8C3306 D271327729B9F9C9AF5F1274FE30B (accessed on 1 March 2020).

86. Kojima, M.; Trimble, C. Making Power Affordable for Africa and Viable for Its Utilities; The World Bank: Washington, DC, USA, 2016; Available online: https:/openknowledge.worldbank.org/bitstream/handle/109 86/25091/108555.pdf?sequence=5isAllowed=y (accessed on 1 March 2020).

87. REN21. Renewables 2019 Global Status Report. 2019. Available online: https://www.ren21.net/wp-content/u ploads/2019/05/gsr_2019_full_report_en.pdf (accessed on 1 March 2020).

88. UNDP. Human Development Data. Available online: http://hdr.undp.org/en/data (accessed on 1 March 2020).

89. UNEP. Atlas of Africa Energy Resources; United Nations Environment Programme: Nairobi, Kenya, 2017; Available online: https://www.icafrica.org/fileadmin/documents/Publications/Africa_Energy_Atlas.pdf (accessed on 1 March 2020).

90. WB. Energy. Available online: https:/www.worldbank.org/en/topic/energy/overview (accessed on 7 March 2019).

91. WB. World Bank Open Data. Available online: https://data.worldbank.org/ (accessed on 1 March 2020).

92. WB. The World Bank in Madagascar. Available online: https://www.worldbank.org/en/country/madagascar/ overview (accessed on 1 March 2020).

93. Harvey, C.A.; Rakotobe, Z.L.; Rao, N.S.; Dave, R.; Razafimahatratra, H.; Rabarijohn, R.H.; Rajaofara, H.; MacKinnon, J.L. Extreme vulnerability of smallholder farmers to agricultural risks and climate change in Madagascar. Phil. Trans. R. Soc. B 2014, 369, 20130089. [CrossRef]

94. WB. Doing Business 2019: Training for Reform. 2019. Available online: https://openknowledge.worldbank. org/handle/10986/30438 (accessed on 1 March 2020).

95. Index Mundi. Consommation d'électricité par habitant-Madagascar. Available online: https://www.inde xmundi.com/map/?v=81000\&r=xx\&l=fr (accessed on 1 March 2020).

96. Georgelin, A. Le Secteur de l'Énergie à Madagascar; Ambassade de France à Madagascar-Service Economique: 2016. Available online: https://ader.mg/pdf_files/infos/Energies_Renouvelables/Etudes/Etude _L $\backslash$ T1 \textquoteright\%C3\%A9nergie_\%C3\%A0_Madagascar_enjeux_et_opportunit\%C3\%A9s_d $\backslash \mathrm{T} 1 \backslash$ textqu oterightaffaires_-_Version_FINALE_290816.pdf (accessed on 1 March 2020). 
97. ONE. Tableau de Bord Environnemental/Région. 2019. Available online: http://mg.chm-cbd.net/cooperation /initiatives/le-projet-combo/metadonnees-sur-la-biodiversite-en-vue-de-planifier-l-absence-de-perte-net te-et/theme-especes/faune-terrestre/tableau-de-bord-environnemental-region-1 (accessed on 1 March 2020).

98. Pavlik, B.J.; Sangster, J.L.; Parsley, I.C.; Knudsen, E.M.; Ndrianajasoloarivony, Z.; Patterson, D.J.; Bartelt-Hunt, S.L.; Jones, E.G. Solar energy for rural Madagascar schools: A pilot implementation by university of Nebraska engineers without borders-USA. Int. J. Serv. Learn. Eng. Humanit. Eng. Soc. Entrep. 2013, 8, 24-42. [CrossRef]

99. Sourisseau, J.-M.; Rasolofo, P.; Belieres, J.-F.; Guengant, J.-P.; Ramanitriniony, H.K.; Bourgeois, R.; Razafimiarantsoa, T.T.; Andrianantoandro, V.T.; Ramarijaono, M.; Burnod, P.; et al. Diagnostic Territorial de la Région du Vakinankaratra à Madagascar; CIRAD, Institut International de Sciences Sociales. 2016. Available online: http://agritrop.cirad.fr/580518/1/Rapport\%20diagnostic\%20prospective\%20Vakinankaratra _VFevrier2016.pdf (accessed on 1 March 2020).

100. Antsa, R. 1.600 milliards Ar d'arriérés de la JIRAMA: Hausse des tarifs en vue pour les grands consommateurs. Available online: http://www.midi-madagasikara.mg/a-la-une/2019/09/25/1-600-milliards-ar-darrieres-de-lajirama-hausse-des-tarifs-en-vue-pour-les-grands-consommateurs/ (accessed on 1 March 2020).

101. Rahaga, N.A. Madagascar se dote de la plus grande centrale solaire de l'Océan Indien. Available online: https: //www.madagascar-tribune.com/Madagascar-se-dote-de-la-plus,23979.html (accessed on 1 March 2020).

102. Transparency International, Country Data, Madagascar, 2019 Rank. Available online: https://www.transpar ency.org/en/countries/madagascar\# (accessed on 7 September 2020).

103. Pradhan, P.; Costa, L.; Rybski, D.; Lucht, W.; Kropp, J.P. A systematic study of Sustainable Development Goal (SDG) interactions. Earth's Future 2017, 5, 1169-1179. [CrossRef]

104. Nilsson, M.; Griggs, D.; Visbeck, M. Policy: Map the interactions between Sustainable Development Goals. Nature 2016, 534, 320-322. [CrossRef] [PubMed]

105. Mika, J.; Farkas, A. On synergies and conflicts between the sustainable development goals (2016-2030) and renewable energy sources for education of and by sustainability. Probl. Educ. 21st Century 2017, 75, 182-193.

106. Millar, D. Endogenous development: Some issues of concern. Dev. Pract. 2014, 24, 637-647. [CrossRef]

107. Del Río, P.; Burguillo, M. Assessing the impact of renewable energy deployment on local sustainability: Towards a theoretical framework. Renew. Sust. Energy Rev. 2008, 12, 1325-1344. [CrossRef]

108. Tremblay, S. Du Concept de Développement au concept de l'Après-Développement: Trajectoire et Repères Théoriques; Université du Québec à Chicoutimi. 1999. Available online: https://constellation.uqac.ca/2029/ (accessed on 1 March 2020).

109. Malunga, C.; Holcombe, S.H. Endogenous Development: Naïve Romanticism or Practical Route to Sustainable African Development; Routledge, 2017; Available online: https://www.routledge.com/Endogenous-Develop ment-Naive-Romanticism-or-Practical-Route-to-Sustainable/Malunga-Holcombe/p/book/9781138294950 (accessed on 1 March 2020).

110. Harris, J.M. Sustainability and sustainable development. In Internet Encyclopaedia of Ecological Economics; Aitken, A.C., Ed.; Internet Encyclopaedia of Ecological Economics, 2003; Available online: https://www.resear chgate.net/publication/237398200_Sustainability_and_Sustainable_Development (accessed on 1 March 2020).

111. Eberhard, A.; Naude, R. The South African Renewable Energy IPP Procurement Programme. 2017. Available online: https://www.researchgate.net/publication/316081773_The_South_African_Renewable_Energy_IP P_Procurement_programme (accessed on 7 September 2020).

112. Wlokas, H.L.; Westoby, P.; Soal, S. Learning from the literature on community development for the implementation of community renewables in South Africa. J. Energy S. Afr. 2017, 28, 35-44. [CrossRef]

(C) 2020 by the authors. Licensee MDPI, Basel, Switzerland. This article is an open access article distributed under the terms and conditions of the Creative Commons Attribution (CC BY) license (http://creativecommons.org/licenses/by/4.0/). 